\title{
Stratigraphy and age of the Cappadocia ignimbrites, Turkey: reconciling field constraints with paleontologic, radiochronologic, geochemical and paleomagnetic data
}

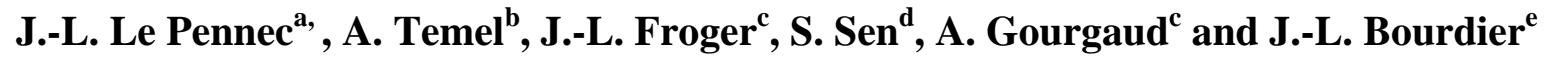 \\ ${ }^{a}$ Institut de Recherche pour le Développement, Whymper 442 y Coruña, AP 17-12-857, \\ Quito, Ecuador \\ ${ }^{\mathrm{b}}$ Hacettepe University, Department of Geological Engineering, 06532 Beytepe, Ankara, \\ Turkey \\ ${ }^{\text {'} U n i v e r s i t e ́ ~ B l a i s e ~ P a s c a l, ~ U M R-C N R S ~ 6524, ~ L a b o r a t o i r e ~ ' M a g m a s ~ e t ~ V o l c a n s ', ~} 5$ rue \\ Kessler, 63038 Clermont-Ferrand, France \\ ${ }^{\mathrm{d}}$ Muséum National d'Histoire Naturelle, UMR-CNRS 8569, Laboratoire de Paléontologie, 8 \\ rue Buffon, 75005 Paris, France \\ ${ }^{\text {e} I S T O, ~ U M R ~} 6113$ CNRS and Université d'Orléans, BP6759, 45067 Orléans cedex 02, France
}

\section{Abstract}

The stratigraphy and age of the Neogene Cappadocia ignimbrites (Central Turkey) have been inferred in previous studies from fieldwork and $\mathrm{K}-\mathrm{Ar}$ age determinations. The resulting stratigraphic schemes, however, differed from each other, suggesting that further studies were required to produce a reliable succession. In this paper, we examine the chronostratigraphy of mammalian remains recovered in the continental sediments interbedded with the Cappadocia ignimbrites. Using recent advances in mammalian chronostratigraphy, we evaluate selected taxa and faunal associations to place new and independent constraints on the ignimbrite ages. The biostratigraphically bracketed ages concur with some published radiometric dates, but they disagree with others, principally at localities where major stratigraphic discrepancies have arisen in the literature. In order to reconcile these apparent inconsistencies, we combine, at selected sites, our field observations with the biostratigraphic and radiometric age limits, and we compare these with the available geochemical and magnetic data. This allows us to present revised age estimates, and a revised stratigraphy which includes the correlation of the local Sofular deposits with the large-volume Gördeles ignimbrite.

The issues faced in this study apply to other ignimbrite provinces in the world. For instance, ignimbrite eruption frequency in Cappadocia is higher than the resolution of many published $\mathrm{K}-\mathrm{Ar}$ ages. Furthermore, different $\mathrm{K}-\mathrm{Ar}$ ages have led to the description of individual and distinct ignimbrites that fieldwork and geochemical data allow to merge into a single ignimbrite. Argon loss from pumice samples leading to radiometric "rejuvenation" provides a likely explanation for most stratigraphic discrepancies. Cappadocia is the only documented ignimbrite field in which the chronostratigraphy of vertebrate remains provides better constraints on some ignimbrite ages than scattered $\mathrm{K}-\mathrm{Ar}$ dates. We further argue that $\mathrm{K}-\mathrm{Ar}$ dates from the Cappadocia area are too imprecise to establish a reliable magnetostratigraphic scheme for the ignimbrite succession, with the exception of the $\sim 2.8 \mathrm{Ma}$ Valibaba Tepe ignimbrite.

Keywords: ignimbrite; geochronology; paleontology; stratigraphy; rock magnetism; Anatolia 


\section{Introduction}

The emplacement of large-volume ignimbrites and deposition of accompanying plinian fallout occur "instantaneously" at geological time scales. Such widespread pyroclastic layers might thus be considered as "ideal" stratigraphic marker horizons at the regional scale. Sequences of overlapping ignimbrites are therefore valuable aids in deciphering the geological history of vast provinces within the time scale of millions of years. However, the deposits of ignimbriteforming eruptions commonly display lateral and vertical variations in sedimentological facies, component types and their proportions, and mineralogical and geochemical characteristics, which all complicate the correlation of discontinuous outcrops. Lithological, petrological, geochemical and magnetic parameters that are useful for correlating deposits between disconnected exposures have been reviewed by Hildreth and Mahood (1985), who stressed that each parameter has advantages and drawbacks and that several lines of evidence should be combined to convincingly support a stratigraphic correlation. Construction of a robust stratigraphic scheme is thus a difficult task, as highlighted in recent revisions of well-studied ignimbrite fields in the western United States and the Andes (e.g., Self et al., 1991, Lipman et al., 1996 and Lindsay et al., 2001).

The Cappadocia area in Central Turkey superbly exposes a succession of Neogene dacitic to rhyolitic ignimbrites and fallout deposits interstratified with continental sediments, in which remains of mammalian fauna occur. In the last four decades, the stratigraphy and correlation scheme of these ignimbrites have been addressed by Pasquarè (1968), Innocenti et al. (1975), Pasquarè et al. (1988), Le Pennec et al. (1994), Mues-Schumacher and Schumacher (1996) and references therein. The ignimbrite stratigraphies presented in these papers rely on fieldworks, and also heavily on $\mathrm{K}$-Ar datings. They differ from each other.

This paper aims to solve the main stratigraphic discrepancies of the current literature. For that purpose, we examine the biochronology of the Neogene mammalian fauna of Central Anatolia and nearby areas. Based on selected taxa and associations, and using recent advances in mammalian chronostratigraphy, we place limits on the age of most Cappadocia ignimbrites. These biostratigraphic age constraints agree with some previous $\mathrm{K}-\mathrm{Ar}$ dates obtained on the ignimbrites and intercalated lavas. They disagree, however, with other published radiometric ages, in particular with $\mathrm{K}$-Ar dates obtained on samples collected at sites where stratigraphic alterations have been introduced in the recent literature. In order to settle the discrepancies, we combine our field observations with the bio- and radiochronologic age constraints, and with the geochemical and magnetic data from the literature. These revisions lead us to propose revised age ranges for the ignimbrites and to correlate two previously separated units, i.e., the Sofular and Gördeles ignimbrites.

\section{Geologic outline and ignimbrite nomenclature}

Convergence of the Afro-Arabian continent toward the Eurasian plate resulted in intense magmatic activity within the Anatolian collage in Neogene times (Innocenti et al., 1982, Dhont et al., 1998 and Piper et al., 2002). Dominantly, calc-alkaline volcanism has developed along separate provinces in Anatolia and surrounding areas (Fig. 1). The Central Anatolian Volcanic Province (CAVP) witnessed episodes of monogenetic activity, stratovolcano growth and emplacement of several large-volume ignimbrite sheets. The Nevsehir Plateau, located in the central part of the CAVP, defines a large tabular structure between the tectonic depressions of the Tuz Göllü to the west and Sultansazlığı to the east and between the 
Kirpehir massif to the north and the Taurus mountain belt to the south (Fig. 1). Emplacement of most rhyolitic ignimbrites took place during Upper Miocene and Pliocene times which, in terms of their continental equivalents, embrace the Vallesian (11.0-8.7 Ma), the Turolian (8.7-5.2 Ma) and the Ruscinian (5.2-3.0 Ma) stages. The Turolian stage comprises the Lower (8.7-7.6 Ma), Middle (7.6-6.7 Ma) and Upper (6.7-5.2 Ma) Turolian subdivisions.

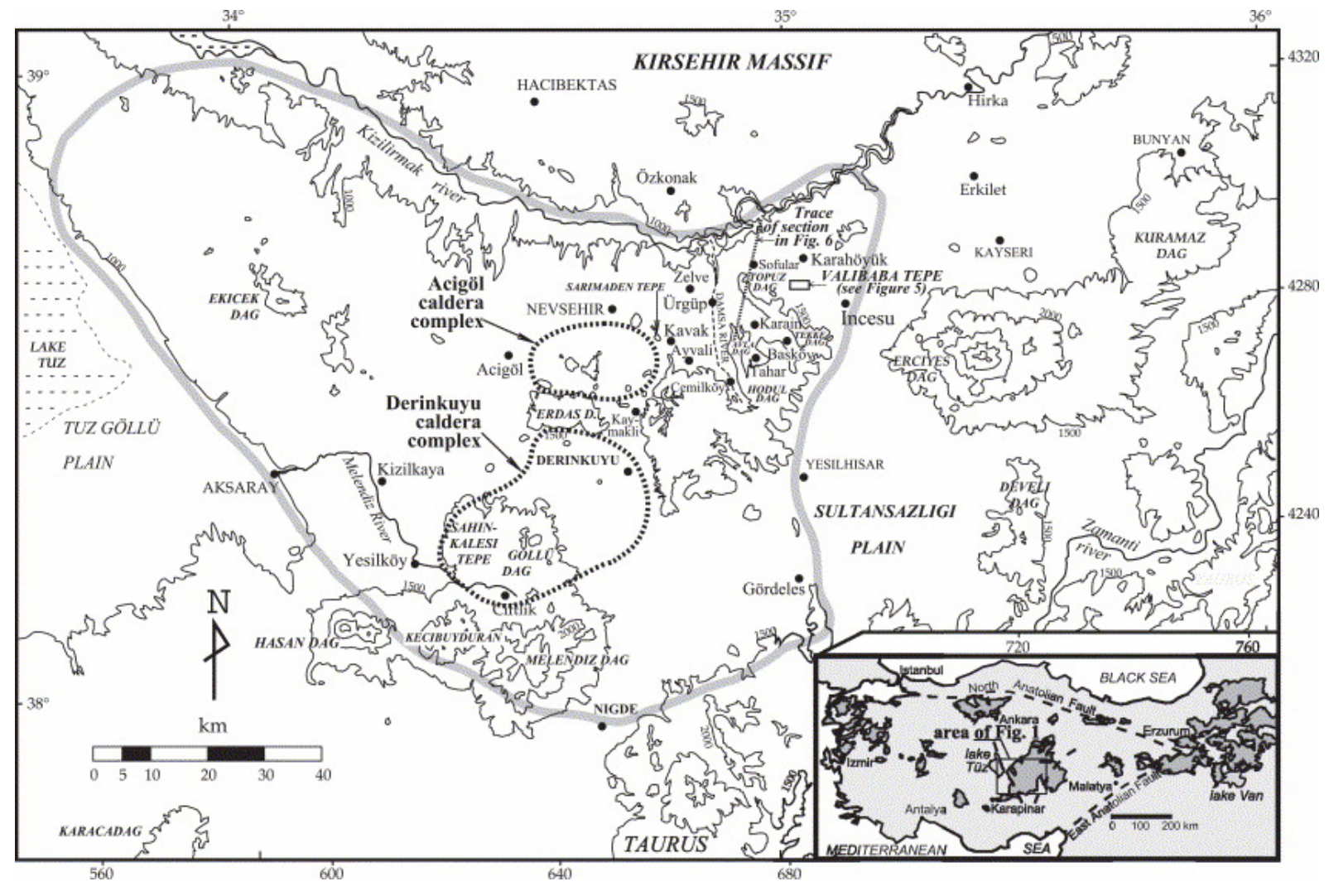

Fig. 1. Sketch map of the Nevşehir Plateau in the Central Anatolian Volcanic Province (CAVP). Contour intervals are $500 \mathrm{~m}$. The thick gray line in the main figure delineates the Nevşehir Plateau. Thick dashed contours in the center of the Nevşehir Plateau are concealed caldera complexes as inferred from geological and geophysical studies of Le Pennec et al. (1994) and Froger et al. (1998). Location of the Valibaba butte (NE of the Nevşehir Plateau) is shown by a box corresponding to the map in Fig. 5. The dashed line NE of the Nevşehir Plateau represents the trace of the geological section of Fig. 6. Inset shows the location of the Nevşehir Plateau in Turkey. Major fault systems (dashed lines), Neogene to Quaternary magmatic provinces (dark gray areas), and major lakes (light gray areas) of Anatolia are also depicted (simplified from Innocenti et al., 1982).

Pasquarè (1968) was the first to produce a comprehensive stratigraphic scheme for the ignimbrite sheets of the Nevşehir Plateau. He named each ignimbrite after villages built on the deposits, e.g., Cemilköy, Gördeles, Incesu, Kavak, Sofular and Tahar units. In other cases, he used the name of a hill ("Tepe" in Turkish), e.g., Sarımaden Tepe and Valibaba Tepe units. Le Pennec et al. (1994) introduced one new name, "Zelve", which is assigned to the ignimbrite cropping out near the village of Zelve. The Zelve unit was previously part of Pasquarè's (1968) Tahar unit, but evidence indicates that the Zelve deposit is distinct and in fact older than the Tahar deposit, as accepted in the subsequent literature. The name "Akdağ-Zelve" introduced by Mues-Schumacher and Schumacher (1996) in place of Zelve is unnecessary and confusing, since Akdağ (meaning "White Hill" in Turkish) recalls the white limestones at the top, and not the pinkish Zelve ignimbrite cropping out at the base of that hill. On the other hand, distinguishing a "Lower" and an "Upper" Göreme (Mues-Schumacher and Schumacher, 1996) as coeval of the "Kavak Member" of Pasquarè (1968) might be appropriate, as these units are separated by reworked material. 


\section{Determining ignimbrite ages}

\subsection{Paleontologic age constraints}

Paleontologic research conducted during the last decades in Cenozoic continental sediments of Eurasia and surrounding regions (including the Middle East and the Mediterranean periphery) has led to recover a number of mammal remains, and to set up their taxonomy, relative biostratigraphy, and to some extent phylogenic relationships. International programs have correlated Cenozoic continental subdivisions of these regions to the geologic time scale by assessing radiometric and magnetostratigraphic results and correlating with dated marine successions. Progressively, the knowledge regarding the chronostratigraphy of the Cenozoic land mammal taxa has been improved. For Europe and nearby areas, the fundamentals of Miocene land mammal chronostratigraphy are compiled in a treatise (Rössner and Heissig, 1999) to which the reader is referred for more details.

Although the Cappadocia ignimbrites locally rest directly on top of each other, in most places, they are interbedded with continental deposits including lacustrine, fluviatile and aeolian sediments and paleosols. Neogene mammalian fossils have been found in these sediments (Fig. 2) and taxonomic determinations reported in Chaput (1936), Şenyürek (1954) and Ozansoy (1962) are compiled in Pasquarè (1968). Later works include those of Sickenberg et al. (1975) and Gaziry (1976). Recent advances in paleontologic research conducted in Anatolia (Sen et al., 1998) allow us to update the taxonomy and the chronostratigraphy of the taxa. The chronostratigraphy of several taxa and associations listed in the above papers is relevant to constrain the age of the ignimbrites. It is also helpful to settle stratigraphic concerns at several localities where discrepancies have arisen in earlier works. Below, we compare the biochronologic data with $\mathrm{K}$-Ar dates of the literature at some selected sites. In most cases, age constraints are in agreement (Fig. 3), but in others, the biochronologic age limits are inconsistent with the $\mathrm{K}$-Ar dates. In this study, we consider that biochronologic ages of selected taxa are more reliable than some conflicting $\mathrm{K}$-Ar dates because they rely on the association of several genus and/or species whose chronostratigraphic distribution is reasonably established in the paleontologic literature (Rössner and Heissig, 1999, and references therein). Moreover, as evidenced below, pumice samples may suffer argon loss leading to significant $\mathrm{K}-\mathrm{Ar}$ age "rejuvenation". 


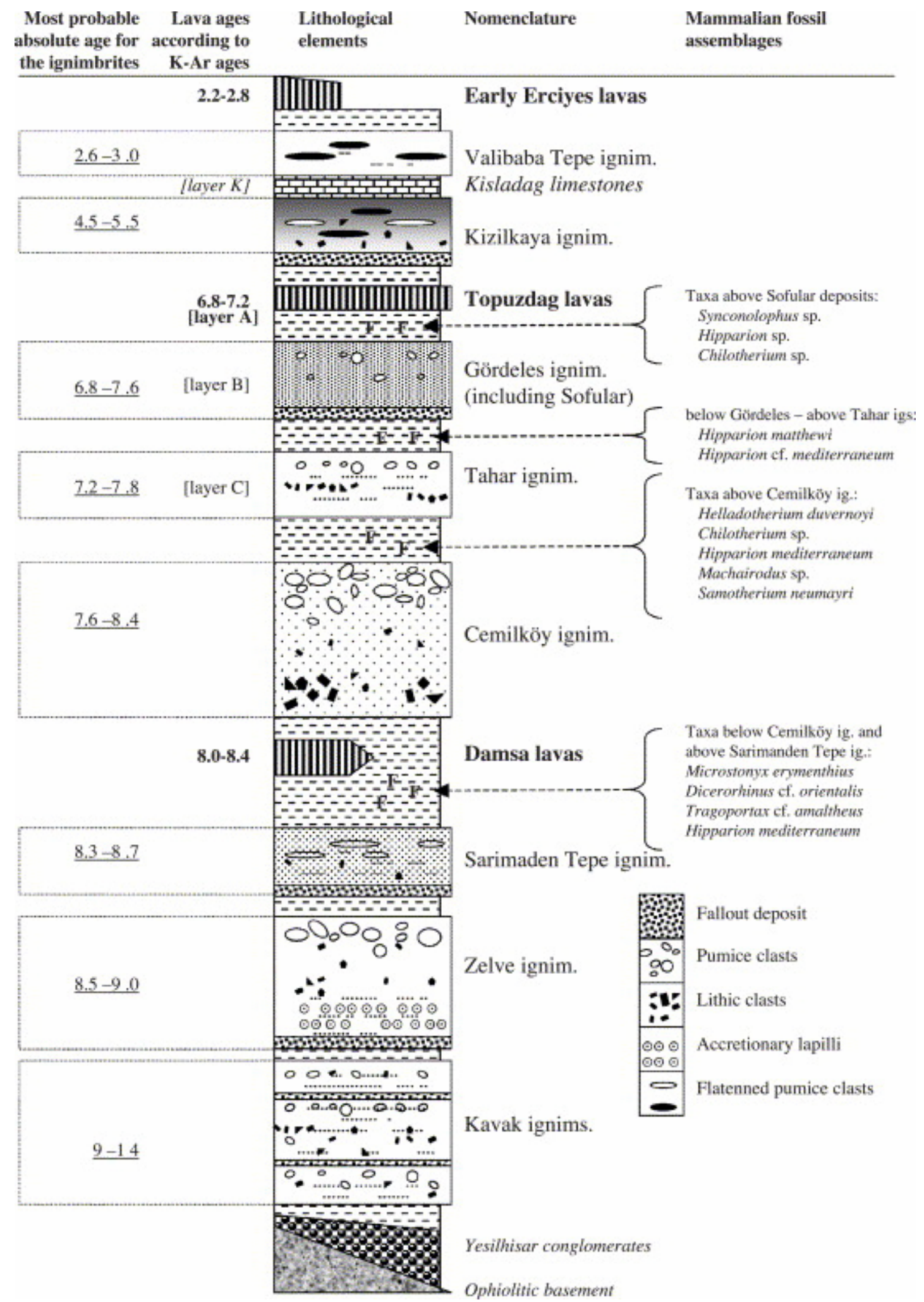

Fig. 2. Schematic stratigraphic column of the Cappadocia ignimbrite succession as proposed in this paper. Lava ages are from $\mathrm{K}-\mathrm{Ar}$ dates in Table 1. Age of the ignimbrites given on the left are constrained from $\mathrm{K}$-Ar dates of Table 1 and from the chronostratigraphy of the mammalian taxa. The taxonomic determinations were compiled by Pasquarè (1968) and are updated in the present study. Note that layers A, B and C refer to the volcanic levels shown in Fig. 4. Layer K refers to the Kışladağ limestones, located between the Kızılkaya and Valibaba Tepe ignimbrites, and is shown in Fig. 4, Fig. 5 and Fig. 6. 


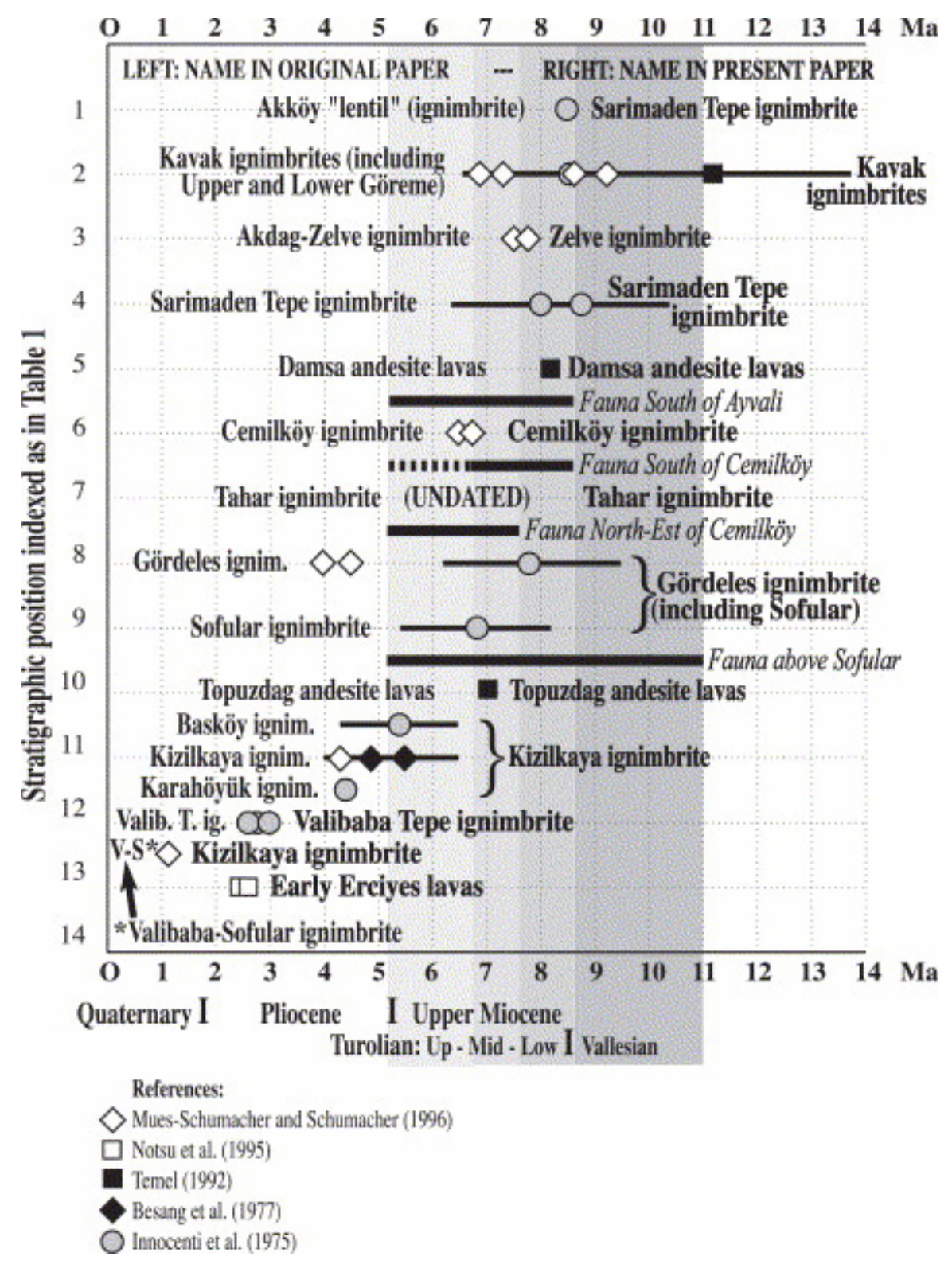

Fig. 3. K-Ar ages of ignimbrites and lavas versus relative stratigraphic position, as indexed in Table 1 and Table 3. Errors of $\mathrm{K}-\mathrm{Ar}$ ages are represented by a thin bar. Note that some symbols are larger than their associated analytical uncertainties. The chronostratigraphic position of the fossil assemblages compiled by Pasquarè (1968) are depicted as thick black bars. Major geochronologic divisions including continental Upper Miocene subdivisions (Upper, Middle and lower Turolian, and Vallesian) are also shown.

\section{2. $\mathrm{K}-$ Ar age constraints and problems}

A few tens of $\mathrm{K}-\mathrm{Ar}$ ages from the Neogene ignimbrites and lavas from the Cappadocia area have been obtained by several laboratories and published during the past three decades. The $\mathrm{K}$-Ar dates were obtained from whole rock and glass samples, and from biotite and plagioclase separates. In this paper, we discuss the $\mathrm{K}-\mathrm{Ar}$ ages regardless of the analytical technique used to obtain them. A review of $\mathrm{K}-\mathrm{Ar}$ dates relevant to the stratigraphy and correlation of the ignimbrites (Table 1) reveals that the resolution of many $\mathrm{K}-\mathrm{Ar}$ ages is lower than ignimbrite eruption frequency (e.g., Innocenti et al., 1975). These ages are thus of limited help when dealing with ignimbrite stratigraphy. More accurate $\mathrm{K}-\mathrm{Ar}$ ages have been used, e.g., by Innocenti et al. (1975), to divide the widespread "Incesu" ignimbrite of Pasquarè 


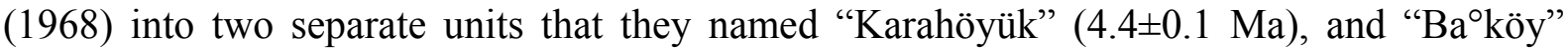
$(5.4 \pm 1.1 \mathrm{Ma})$. Later, Besang et al. (1977) obtained analytically distinct ages of $4.9 \pm 0.2 \mathrm{Ma}$ and $5.5 \pm 0.2 \mathrm{Ma}$ on their "Kizılkaya" unit which corresponds to the "Incesu" unit of Pasquarè (1968). In fact, simple physical continuity of the deposits allows these four ages to be assigned to a single conspicuous ignimbrite, as shown by Pasquarè et al. (1988) and Le Pennec et al. (1994) and as supported by the geochemical data of Temel et al. (1998). These four ages yield a weighted average age of $5.0 \pm 0.9 \mathrm{Ma}$ which contrasts with the three $\mathrm{K}-\mathrm{Ar}$ ages that cluster around 4.3 Ma (Table 1) obtained from the same Kizılkaya ignimbrite by Mues-Schumacher and Schumacher (1996). Similarly, these latter authors quote four accurate ages for their "Upper Göreme" unit, but all are analytically distinct, ranging between $6.9 \pm 0.2$ $\mathrm{Ma}$ and 9.2 $\pm 0.2 \mathrm{Ma}$. Therefore, most published $\mathrm{K}-\mathrm{Ar}$ ages obtained for the Cappadocia succession should be used as rough indicators of ignimbrite age, rather than definitive "absolute" age.

Table 1. : K-Ar ages and nomenclature relevant to the ignimbrite stratigraphy of Cappadocia

\begin{tabular}{|c|c|c|c|c|c|c|c|c|c|c|c|c|}
\hline \multicolumn{2}{|c|}{$\begin{array}{l}\text { Stratigraphic } \\
\text { Iewel }\end{array}$} & $\begin{array}{l}\text { Unit name } \\
\text { in } \\
\text { Pasquare }\end{array}$ & $\begin{array}{l}\text { Name in } \\
\text { Innocenti } \\
\text { et al. }\end{array}$ & \multirow[t]{2}{*}{$\begin{array}{c}\text { Age } \\
\text { Ma } \\
\text { (ti- error) }\end{array}$} & $\begin{array}{|cc|}\text { Name in } & \text { Age } \\
\text { Besang } & \text { Ma } \\
\text { et al. } & (+1-\text {-erros }) \\
\end{array}$ & $\begin{array}{l}\text { Age in } \\
\text { Temel }\end{array}$ & $\begin{array}{l}\text { Name in } \\
\text { Le Pennec } \\
\text { et al. }\end{array}$ & $\begin{array}{l}\text { Age in } \\
\text { Notsu } \\
\text { et al. }\end{array}$ & $\begin{array}{c}\text { Name in } \\
\text { Mues-Schumacher } \\
\text { and Schumacher }\end{array}$ & \multirow[t]{2}{*}{$\begin{array}{c}\text { Age In } \\
\text { Ma } \\
\text { (ti- errof) } \\
\end{array}$} & \multirow[t]{2}{*}{$\begin{array}{l}\text { Name in } \\
\text { this study }\end{array}$} & $\begin{array}{c}\text { most } \\
\text { probable } \\
\text { age range }\end{array}$ \\
\hline & & 1968 & 1975 & & 1977 & 1992 & 1994 & 1995 & 1996 & & & in $\mathrm{Ma}$ \\
\hline 13 & $\begin{array}{l}\text { LAVAS } \\
\text { LAVAS }\end{array}$ & $\begin{array}{l}\text { Erclyes } \\
\text { Erclyes }\end{array}$ & & & & & & $\begin{array}{l}2.5+1-0.3 \\
2.8+t-0.1\end{array}$ & & & & 2.2 .28 \\
\hline 12 & IGNIMBAITE & Valibaba Tepe & Valibaba Tepe & $\begin{array}{l}2.7+0.0 .1 \\
2.8+\gamma-0.1 \\
3.0+\% 0.1\end{array}$ & & & Valibaba Tepe & & $\begin{aligned} & \text { Valibaba-solular } \text { Incesu } \\
&\end{aligned}$ & $\frac{1.1+\gamma-0.1}{2.8+\lambda-0.1}$ & Valbaba Tepe & $2.6 \cdot 3.0$ \\
\hline 11 & IGNIMBAITE & Incesu & $\frac{\text { Karahoyūk }}{\text { Baskóy }}$ & $\frac{4.4+8-0.1}{5.4+6-1.1}$ & Kizilkaya $\begin{array}{l}4.9+i-0.2 \\
5.5+i-0.2\end{array}$ & & Kizilkaya & & Kizikaya & $\begin{array}{l}4.3+i-0.2 \\
4.3+i-0.2 \\
4.5+i-0.2\end{array}$ & Kizilkaya & $4.5-5.5$ \\
\hline 10 & LAVAS & Topuz dag & & & & $7.0 \times 02$ & & & & & zdey & $6.8 \cdot 72$ \\
\hline 9 & IGNIMOAITE & Solular & Sofular & $6.8+1-1.4$ & & & Sofular & & Valibaba-Sofular & $1.1+k-0.1$ & & \\
\hline 8 & IGNIMBAITE & Gordeles & Gordeles & $7.8+1-1.6$ & & & Gördeles & & Gördeies & $4.0+1=0.2$ & Górdeles & $6.8 \cdot 7.6$ \\
\hline 7 & IGNIMBAITE & Tanar & Tahar & & & & Tahar & & Tahar & & Tahar & $7.2 \cdot 7.8$ \\
\hline 6 & IGNIMBAITE & Cemilkőy & Cemilkôy & & & & Cemilkơy & & Cemilkoy & $\begin{array}{l}6.5+1-0.2 \\
6.8+i-0.2\end{array}$ & Cemilkőy & $7.6-8.4$ \\
\hline 5) & LAVAS & Damsa & & & & $8.2+60.2$ & & & & & Daman & $8.0 \cdot 8.4$ \\
\hline 4] & IGNIMBAITE & Sarimaden Tepo & Sarimaden Tepe & $\begin{array}{l}8.0+j-1.6 \\
8.6+j-1.7 \\
\end{array}$ & & & Sarimaden & & Sarimaden & & Sarimaden Tepe & $8.3-8.7$ \\
\hline 3 & IGNIMBRITE & (not identitied) & (not ident: & (fied) & & & Zelve & & Akdag-Zelve & $\begin{array}{l}7.5+1-0.2 \\
7.7+1-0.2\end{array}$ & Zelve & $8.5 \cdot 9.0$ \\
\hline 2 & $\begin{array}{c}\text { GROUP OF } \\
\text { GNIMBAITES }\end{array}$ & Kavaik & Kavak & $8.6+1.1 .7$ & & $11.2+1 \cdot 2.5$ & Kavak & & Upper Gôreme & $\begin{array}{l}6.9+1-0.2 \\
7.3+1-0.2 \\
8.7+1-0.2 \\
9.2+1-0.2 \\
\end{array}$ & Kavak ignimbrhes & $9.0 \cdot 14$ \\
\hline & & & & & & & & & Lower Góreme & & & \\
\hline 1] & IGNIMBAITE & Alokoy & & $8.5+1-0.2$ & & & & & & & & \\
\hline
\end{tabular}

Note that the Sofular and Gördeles units are considered as a single ignimbrite in this paper. The most probable ages proposed in the present study are also listed.

Fig. 3 compares the $\mathrm{K}-\mathrm{Ar}$ ages of the literature with the stratigraphic position of dated units in the Cappadocia succession (Table 1). Taking the uncertainties into account, the ages obtained by Innocenti et al. (1975), Besang et al. (1977) and Temel (1992) are internally consistent on a broad scale. Some of the K-Ar ages obtained by Mues-Schumacher and Schumacher (1996) also compare well with previously published ages but others seem too young. These authors ascribe the relative youthfulness of these pumice samples to alteration and argon loss. This is likely the case because all ignimbrites from the Cappadocia succession suffered vapor-phase alteration and weathering, as evidenced by high loss on ignition (LOI) values in pumice samples (Temel et al., 1998) and by magnetic studies of the deposits (Le Pennec et al., 1998 and Piper et al., 2002). In addition, some ignimbrites were emplaced in, or later covered by lake waters, thus enhancing alteration processes. As discussed below, an extreme case of $\mathrm{K}-$ Ar age rejuvenation is given by one age determination for the "Sofular-Valibaba" unit of Mues-Schumacher and Schumacher (1996) which strongly conflicts with field, radiometric and paleontologic evidence. This, in turn, has implications for their stratigraphic and 
correlation schemes, and for the magnetostratigraphy proposed by Piper et al. (2002) which is based on the stratigraphy and K-Ar ages of Mues-Schumacher and Schumacher (1996).

\section{Reconciling field, paleontologic and geochronologic discrepancies}

In this section, we examine the stratigraphy at selected sites, where in our opinion a collection of multidisciplinary arguments can be brought together to settle major stratigraphic concerns. Our field observations were obtained during missions conducted between 1989 and 2003. Some of these were briefly described in Le Pennec et al. (1994); others are discussed in detail here for the purpose of reassessing the stratigraphy at selected key-sites.

\subsection{The Akköy village and Damsa valley area}

Pasquarè (1968) defined his “Akköy lentil” near Akköy village as a local welded ignimbrite lying underneath his "Kavak Member" (Table 1). Yet, field evidence led us to place the "Akköy lentil" above the conspicuous Zelve plinian fall deposit, which overlies the Kavak ignimbrites at other localities. Hence, the "Akköy lentil" was correlated by Le Pennec et al. (1994) with the Sarımaden Tepe ignimbrite because it bears similar characteristics and occurs at the same stratigraphic level. Innocenti et al. (1975) obtained an age of $8.5 \pm 0.2 \mathrm{Ma}$ for the "Akköy" unit, consistent with the less accurate ages obtained by them for the Sarımaden Tepe ignimbrite $(8.0 \pm 1.6$ and 8.6 $\pm 1.7 \mathrm{Ma}$, Table 1). Mues-Schumacher and Schumacher (1996) also adopted the correlation of the "Akköy" deposit with the Sarımaden Tepe unit, although they obtained a somewhat younger weighted age of 7.6 \pm 0.4 Ma for their "Akdağ-Zelve" unit (our Zelve) which is located below the Sarımaden Tepe unit (Fig. 2).

A similar age problem occurs in the Damsa valley, south of Ürgüp, where the voluminous non-welded Cemilköy ignimbrite overlies the welded Sarımaden Tepe unit. The so-called Damsa andesite lavas lie between the two units and have been dated at $8.2 \pm 0.2 \mathrm{Ma}$ (Temel et al., 1998). Taking analytical errors into account, this age is compatible with those obtained for the older Sarımaden Tepe unit by Innocenti et al. (1975) and for the younger Cemilköy unit dated by Mues-Schumacher and Schumacher (1996). Indeed, it conflicts with the weighted average age of 7.6 \pm 0.4 Ma obtained by Mues-Schumacher and Schumacher (1996) for their "Akdağ-Zelve" ignimbrite (our Zelve), which is stratigraphically older than both the Damsa valley andesite lavas and the Sarımaden Tepe unit (Table 1, Fig. 2). Paleontologic age constraints as assessed in this study, suggest a Lower to Middle Turolian age for the Cemilköy ignimbrite (i.e., 8.7-6.7 Ma), consistent with the above $\mathrm{K}-\mathrm{Ar}$ ages: in his compilation, Pasquarè (1968) reports an assemblage of mammalian fossils in a lateritic paleosol located just below the Cemilköy deposit (Fig. 2). Taxa like Microstonyx erymenthius (Rodler and Weithofer) and Dicerorhinus cf. orientalis (Schlosser) support a Turolian age, i.e., between 8.7 and 5.2 Ma, while Tragoportax cf. amaltheus (Rodler and Weithofer), and Hipparion mediterraneum (Schlosser) are rarely reported in the literature after Middle Turolian times, i.e., after $6.7 \mathrm{Ma}$. Although not very accurate, these age constraints are roughly compatible with $\mathrm{K}-\mathrm{Ar}$ ages of the ignimbrites (Fig. 3). Mammalian remains resting above the Cemilköy unit are also reported by Pasquarè (1968) near Cemilköy village. The author cited Helladotherium duvernoyi (Gaudry) and Chilotherium sp., two taxa of EarlyMiddle Turolian age (8.7 to 6.7 Ma) in eastern Mediterranean areas. Chaput (1936), Pasquarè (1968) andSickenberg et al. (1975) reported a rich mammalian assemblage near Karain village, southeast of Ürgüp. Sickenberg et al. (1975) found paleontologic remains $1 \mathrm{~km}$ WNW 
of Karain village (at the Ören locality, thus above the Cemilköy unit), and attributed the fauna to the Late Vallesian (9.7-8.7 Ma) or Early Turolian (8.7-7.6 Ma) stages. Recent investigations of Late Miocene mammalian associations in Turkey (Sen, 1994 and Sen et al., 1998) indicated that these faunal assemblages are best correlated with the Early Turolian. Two K-Ar dates by Mues-Schumacher and Schumacher (1996) on the Cemilköy unit yielded ages of $6.5 \pm 0.2 \mathrm{Ma}$ and $6.8 \pm 0.2 \mathrm{Ma}$ (Table 1), which seem slightly too young in light of the biochronologic constraints discussed here. These $\mathrm{K}-\mathrm{Ar}$ ages are also in conflict with the $7.0 \pm 0.15 \mathrm{Ma}$ age obtained by Temel (1992) on the stratigraphically much younger Topuzdağ lavas (Table 1, Fig. 2 and Fig. 3), as discussed later. Combining the K-Ar ages with the biochronologic ages and with the age of the underlying units (Damsa lavas, Sarımaden Tepe ignimbrite) leads us to propose most probable age brackets of 7.6-8.4 Ma for the Cemilköy unit. For the Sarımaden Tepe unit, which includes the "Akkoy lentil" of Pasquarè (1968), the most probable age can be placed between 8.3 and $8.7 \mathrm{Ma}$, in agreement with the $\mathrm{K}$-Ar dates of Innocenti et al. (1975). The Zelve ignimbrite eruption most likely took place between 8.5 and $9.0 \mathrm{Ma}$, and the $\sim 7.6 \mathrm{Ma} \mathrm{K}$-Ar dates obtained by Mues-Schumacher and Schumacher (1996) possibly reflect argon loss in the samples.

\subsection{Area around Sofular village}

Despite good exposures, there is great confusion in the stratigraphy, nomenclature, and correlation of the units cropping out around Sofular village (Fig. 1). This area is critical to the stratigraphy of the ignimbrites and several problems can be clarified there. A photo taken 1.5 $\mathrm{km}$ southwest of Sofular village, shows the Topuz mountain as seen from the North (Fig. 4). Three volcanic layers A, B and C are dipping toward the north. Layer A is the Topuzdag andesitic lavas dated at $7.0 \pm 0.15 \mathrm{Ma}$ by Temel (1992), which are topped by $5-10 \mathrm{~m}$ of white limestones (layer K, belonging to the Kışladağ member of Pasquarè, 1968). Layer B is a consolidated, fine-grained biotite-rich ignimbrite with a yellowish fallout layer at the base. Layer $\mathrm{C}$ is also an ignimbrite layer. In regard to the site where the picture was taken, MuesSchumacher and Schumacher (1996) write that "the road between Sofular and Sarýhýdýr exposes a massive ignimbrite (...). The internally layered pumice-fall deposit underneath identifies the deposit as the Valibaba-Sofular ignimbrite [layer B of Fig. 4 in the present paper], which overlies a light-grey welded ignimbrite [layer C of Fig. 4 in the present paper] with non-welded basal zone and with well defined gas-escape structure". All previous studies have correlated layer B to the Sofular ignimbrite (equivalent to the above Valibaba-Sofular unit of Mues-Schumacher and Schumacher, 1996), as first defined by Pasquarè (1968). Divergence arises when correlating layer C.

Pasquarè (1968) assigned layer C to his "Incesu" unit. He defined this later ignimbrite as a commonly welded deposit with abundant biotite and feldspar crystals. However, the ignimbrite cropping out in the village of Incesu (NW of the Sultansazlığ depression, Fig. 1), is welded but crystal-poor and biotite-free. In fact, the characteristics of the welded biotitefree ignimbrite observed at Incesu village are similar to those of the Valibaba Tepe unit described by Pasquarè (1968). The type-sections where Pasquarè (1968) defined his biotiterich Incesu ignimbrite and the areal distribution given in Pasquarè et al. (1988) indicate that the locality name Incesu (i.e., a place where the exposed unit is biotite-free) can no longer be retained to describe the conspicuous red-tinted, columnar-jointed and biotite-rich unit which covers the entire Nevssehir Plateau on top of the ignimbrite succession. Instead, Beekman (1966), Schischwani (1974) and Besang et al. (1977) introduced the name Kizilkaya to describe this unit and this has been adopted in later works (Le Pennec et al., 1994, Schumacher and Mues-Schumacher, 1996, Mues-Schumacher and Schumacher, 1996, Froger 
et al., 1998, Le Pennec et al., 1998, Temel et al., 1998, Le Pennec, 2000 and Piper et al., 2002). Using the most recent nomenclature, we assume that Pasquarè (1968), Pasquarè et al. (1988), Schumacher and Mues-Schumacher (1996), Mues-Schumacher and Schumacher (1996), and Piper et al. (2002), correlate layer C at Topuz mountain with the Kizilkaya ignimbrite, whose most probable age is $4.5-5.5 \mathrm{Ma}$, as discussed later. Here, we present several lines of evidence against this correlation.

\begin{tabular}{|c|c|c|c|c|c|c|}
\hline \multirow{2}{*}{\multicolumn{2}{|c|}{\begin{tabular}{|l} 
Kisladag \\
\end{tabular}}} & & & & S-SE & N-NW \\
\hline & & & & & \multirow{2}{*}{\multicolumn{2}{|c|}{$\begin{array}{l}\text { Layer } \mathrm{K} \rightarrow \\
\text { Layer } \mathrm{A} \rightarrow\end{array}$}} \\
\hline $\begin{array}{l}\text { Topuzdag } \\
\text { lavas }\end{array}$ & $\begin{array}{l}\text { Topuzdag } \\
\text { lavas }\end{array}$ & $\begin{array}{l}\text { Topuzdag } \\
\text { lavas }\end{array}$ & & $\begin{array}{l}\text { Topuzdag lav. } \\
7.0+/-0.2 \mathrm{Ma}\end{array}$ & & \\
\hline Sofular ig. & $\begin{array}{l}\text { Sofular ig. } \\
6.8+1-1.4 \mathrm{Ma}\end{array}$ & Sofular ig. & $\begin{array}{l}\text { Valibaba-Sofular ig. } \\
1.1+1-0.1 \mathrm{Ma}\end{array}$ & Sofular ig. & Layer B - & \\
\hline Incesu ig. & Incesu ig. & Tahar ig. & $\begin{array}{l}\text { Kizilkaya ig. } \\
4,3+1-0.1 \text { Ma }\end{array}$ & Tahar ig. & Layer $\mathrm{C} \rightarrow$ & \\
\hline $\begin{array}{l}\text { Pasquare } \\
\text { (1968) }\end{array}$ & $\begin{array}{l}\text { Innocenti } \\
\text { et al. } \\
(1975)\end{array}$ & $\begin{array}{l}\text { Le Pennec } \\
\text { et al. } \\
(1994)\end{array}$ & $\begin{array}{l}\text { Mues-Schumacher } \\
\text { and Schumacher } \\
\text { (1996) }\end{array}$ & $\begin{array}{l}\text { Temel } \\
\text { et al. } \\
(1998)\end{array}$ & & \\
\hline
\end{tabular}

Fig. 4. View of Topuz mountain from the North, taken from $1.5 \mathrm{~km}$ to the SW of Sofular village. A comparison of the stratigraphy, nomenclature, and $\mathrm{K}-\mathrm{Ar}$ ages of the literature is given in the table on the left. Layer $\mathrm{K}$ belongs to the Kışladağ limestone member of Pasquarè (1968).

(1) Pasquarè (1968) reported an assemblage of mammalian fossils, just above layer B (Fig. 2), from a locality near the site where the photo in Fig. 4 was taken. He cited Synconolophus sp., Hipparion sp. and Chilotherium sp. In recent studies, the genus Synconolophus is included in Choerolophodon, a taxon known from Middle to Late Miocene times in Eastern Africa, India and the Middle East (Gaziry, 1976). The genus Hipparion spanned from Late Miocene to Late Pliocene times. The presence of Chilotherium sp. is critical because, in the Middle East, this genus did not survive after Middle Turolian times (after 6.7 Ma). Therefore, it is unlikely that layer $\mathrm{C}$, stratigraphically situated below this fossil association and below the dated layer A ( $\sim 7$ Ma, Fig. 4), corresponds to the 4.5- to 5.5-Ma-old Kizilkaya ignimbrite. Similarly, the age of this fossil assemblage is in conflict with the $1.1 \pm 0.1$ Ma age obtained by Mues-Schumacher and Schumacher (1996) for their Valibaba-Sofular unit, which corresponds to layer B in Fig. 4. In contrast, the age of this fauna is consistent with the $\mathrm{K}-\mathrm{Ar}$ age of 6.8 $1.4 \mathrm{Ma}$ obtained for the Sofular deposit (layer B) by Innocenti et al. (1975), and the age of 7.0 $\pm 0.15 \mathrm{Ma}$ for the overlying Topuzdağ lavas (layer A) reported by Temel (1992).

(2) Mues-Schumacher and Schumacher (1996) described layer C as being a welded ignimbrite (see above) and we infer that, based on this feature, they correlated layer C of Fig. 4 with the partially welded Kizilkaya ignimbrite. Our own observations of the deposit at that site and nearby outcrops indicate that layer $\mathrm{C}$ is strongly cemented but not welded. In nearby areas, it exhibits columnar jointing, a feature that does not necessarily imply welding of the deposit. Regular jointing is also described in non-volcanic deposits, e.g., sandstones (Buist, 1980). We have observed that regular columnar jointing occurs in layer $\mathrm{C}$ where it directly overlies lacustrine marl or limestone sediments.

(3) Layer $\mathrm{C}$ shows distinct flow-units with internal stratification and notable pumice and lithic concentration zones. We have not observed the Kizllkaya ignimbrite in the area shown in Fig. 
4. However, the closest exposures of the Kizllkaya ignimbrite known to us in the northeastern region of the Nevşehir Plateau display a massive non-welded deposit locally underlain by a thin $(\mathrm{few} \mathrm{cm})$ fallout layer.

(4) Pumice clasts in layer C are commonly more or less rounded and equant in shape, relatively dense, with sub-spherical bubbles. On the other hand, pumice fragments in the nonwelded parts of the Kizılkaya unit are typically of lower density, with vesiculation textures dominated by irregular fibrous shapes, and richer in crystals than pumice in layer $\mathrm{C}$.

(5) Mues-Schumacher and Schumacher (1996) dated their biotite-rich "Valibaba-Sofular" unit at $\approx 1.1 \mathrm{Ma}$ at Valibaba butte (see below) and assigned this age to layer B of Fig. 4. This would imply unrealistically high erosional rates in the area. If layer B is $\approx 1.1 \mathrm{Ma}$ old, the overlying deposits (in Fig. 4 fine-grained clastic sediments, marls, clays, lavas, and 5-10 m of white limestones overly layer B) would have accumulated very quickly before being eroded to depths of $>150-250 \mathrm{~m}$ over vast areas. In contrast, supposedly contemporaneous obsidian lavas extruded in the central part of the Nevşehir Plateau and dated between 1.0 and 1.3 Ma by Bigazzi et al. (1993) have a much younger morphology. In the Göllü Dað area, surface morphology of lavas is locally well preserved, and associated pyroclastic deposits are still poorly consolidated. In addition, erosion gullies have depths rarely exceeding 30-50 m.

The characteristics of layer $\mathrm{C}$ in the area shown in Fig. 4 allow us to correlate this layer with the Tahar unit, as first described at Tahar village by Pasquarè (1968) who interpreted it initially as a lahar deposit, and later as an ignimbrite (Pasquarè et al., 1988). This correlation is consistent with the stratigraphy observed around Tahar village, where in our interpretation, a similar deposit occurs above the Cemilköy unit and below the Gördeles and Kızılkaya units (Fig. 2). Pumice clasts in the Tahar unit have a mineral assemblage similar to that in the Kizilkaya ignimbrite. However, significant geochemical differences exist between these units (Table 2). Major and trace element analyses of pumice clasts in layer $\mathrm{C}$ near Topuz mountain (Fig. 4) and of pumices in a similar deposit near Tahar village indicate that pumices in layer $\mathrm{C}$ are more basic in composition than those in the younger K1z1lkaya unit (67-71\% and $71-73 \%$ $\mathrm{SiO}_{2}$, respectively; Temel et al., 1998). The Kizilkaya unit is significantly richer in incompatible elements like $\mathrm{Rb}, \mathrm{Ba}, \mathrm{La}, \mathrm{Ce}$ and depleted in more compatible elements such as $\mathrm{Zr}$ and Sr. Similarly, isotopic ratios show noticeable differences. For example, ${ }^{87} \mathrm{Rb} /{ }^{86} \mathrm{Sr}$ ratios are twice as high in the Kizılkaya unit than those in the Tahar unit.

Table 2. : Selected mineralogical and geochemical data for different ignimbrite units

\begin{tabular}{|c|c|c|c|c|c|c|c|c|c|c|c|c|c|c|}
\hline $\begin{array}{l}\text { Ignimbrite } \\
\text { unit } \\
\end{array}$ & $\begin{array}{l}\text { Silica } \\
\text { range (\%) }\end{array}$ & $\begin{array}{l}\mathrm{Plg} \\
\mathrm{An} \%\end{array}$ & $\begin{array}{l}\text { Mica } \\
\left(\mathrm{Mg}^{*}\right)\end{array}$ & Qz & $\begin{array}{l}\text { Amph } \\
\left(\mathrm{Mg}^{*}\right)\end{array}$ & Cpx & Opx & ${ }^{87} \mathrm{Rb} /{ }^{86} \mathrm{Sr}$ & $\begin{array}{l}\mathrm{CeN} / \\
\mathrm{YbN}\end{array}$ & $\mathrm{Sr}$ & $\mathrm{Zr}$ & $\mathrm{Rb}$ & $\mathrm{Nb}$ & $\mathrm{Ba}$ \\
\hline Valibaba Tepe & $65-66$ & $22-56$ & - & - & - & + & + & $2.79-2.80$ & - & $215-227$ & $363-373$ & $114-115$ & 14 & $490-530$ \\
\hline Kizilkaya & $71-73$ & $31-54$ & $64-68$ & + & \pm & - & - & $4.39-4.67$ & 9.37 & $120-127$ & $124-138$ & $193-194$ & $8.1-12.7$ & $670-678$ \\
\hline Sofular & $70-73$ & $25-47$ & $65-68$ & \pm & - & - & - & $3.26-6.81$ & - & $88-91$ & $141-157$ & $188-211$ & $15.9-16.1$ & $877-922$ \\
\hline Gördeles & $68-69$ & $30-54$ & $60-64$ & \pm & \pm & + & - & 3.09 & 6.63 & $170-174$ & $237-248$ & $186-192$ & $16.5-17$ & $657-679$ \\
\hline Tahar & $67-71$ & $16-79$ & + & \pm & $64-69$ & \pm & - & $2.19-2.28$ & 7.75 & 173 & $181-193$ & $131-137$ & $9.4-18$ & $588-594$ \\
\hline Cemilköy & $72-74$ & $25-87$ & $50-72$ & \pm & $61-70$ & - & - & $7.25-8.75$ & 7.92 & $70-81$ & $83-96$ & $204-221$ & $8.6-10.7$ & $786-805$ \\
\hline Sarimaden & $69-70$ & $25-61$ & $63-67$ & \pm & - & \pm & - & 4.05 & - & 118 & 214 & 165 & 14.8 & 822 \\
\hline Zelve & $71-75$ & $30-57$ & $57-63$ & + & - & - & - & 2.97 & 10.67 & $155-166$ & $102-111$ & $171-173$ & $15.3-16.9$ & $1009-1050$ \\
\hline Kavak & $68-72$ & $29-41$ & $54-61$ & + & - & - & - & 2.06 & 9.12 & $229-241$ & $102-104$ & $172-173$ & $14.7-15.3$ & $932-949$ \\
\hline
\end{tabular}

Plg: plagioclase, An: anorthite content, $\mathrm{Mg}^{*}: \mathrm{Mg} /(\mathrm{Mg}+\mathrm{Fe}) \times 100$, Qz: quartz, Amph.: amphibole, Cpx: clinopyroxene, Opx: orthopyroxene. The Sofular and Gördeles units are considered as a single ignimbrite in this paper. The analyses were carried out on pumice samples and are compiled from Temel et al. (1998). 
The correlation of layer $\mathrm{C}$ with the Tahar unit is also substantiated by observed flow patterns. In the area shown in Fig. 4, dark xenoliths within the whitish ash matrix of layer $\mathrm{C}$ show clear imbrication toward the north and northwest. This flow pattern does not match that obtained by us in nearby areas for the Kizilkaya ignimbrite. In the nearest exposures known to us, the Kizilkaya ignimbrite shows a stable flow direction toward the NE, as evidenced by the imbrication of clasts and crystals at the base of the ignimbrite, and by the orientation of acicular wood pieces at the contact between the underlying fall layer and the ignimbrite (Le Pennec, 2000). Furthermore, maximum clast-size variations in the associated fall layer (Le Pennec et al., 1994), magnetic fabric studies of Le Pennec et al. (1998) and Piper et al. (2002) in the Kizilkaya unit also lend support to this flow pattern, as discussed below.

Finally, correlating layer $\mathrm{C}$ of Topuz Mountain with the Tahar ignimbrite is consistent with existing isopach and isopleth maps (Le Pennec et al., 1994), as well as with all bio- and radiochronologic constraints mentioned earlier. One exception, however, is the $1.1 \pm 0.1 \mathrm{Ma}$ age of Mues-Schumacher and Schumacher (1996) and we present below additional evidence which casts further doubt on the reliability of this age.

\subsection{The Valibaba butte area}

Valibaba Tepe is a small butte (Fig. 5) located $\sim 17 \mathrm{~km}$ northeast of Ürgüp and $\sim 4.5 \mathrm{~km}$ west of Karahöyük village. Pasquarè (1968) defined the Valibaba Tepe unit as a crystal-poor, biotite-free, strongly welded ignimbrite with an eutaxitic fiamme-rich texture. However, Mues-Schumacher and Schumacher (1996) write that the Valibaba Tepe butte is definitely not formed by a densely welded ignimbrite and report one $\mathrm{K}-\mathrm{Ar}$ date on a biotite fraction from a sample collected at that butte. We believe that this contradiction arises because the butte comprises two superposed ignimbrite units (Fig. 5), as shown in the geological map of Pasquarè (1968) and as briefly mentioned in Le Pennec et al. (1994). The lowest part of the butte consists of a non-welded ignimbrite with features similar to the Kizılkaya ignimbrite (fines-depleted matrix with distinctive tabular plagioclase crystals, abundant biotite crystals, 5-15 cm large fibrous pumices, etc.). White massive limestones belonging to the "Kışladağ Member" of Pasquarè (1968) are found overlying the non-welded ignimbrite (Fig. 5). Above the limestones, the butte is coated with a thin (few decimeters), strongly welded layer that displays the typical characteristics of the biotite-free Valibaba Tepe unit, as described by Pasquarè (1968). Because Mues-Schumacher and Schumacher (1996) obtained their K-Ar result from a biotite fraction at Valibaba butte, we assume that they dated the lower ignimbrite deposit (which we correlate with the K1zılkaya unit) rather than the Valibaba Tepe ignimbrite defined by Pasquarè (1968). Another possibility is that they sampled the nearby Büyükkazan Kaya hill (Fig. 5), $1 \mathrm{~km}$ East of Valibaba butte, where the lower non-welded unit and the Kışladağ limestones are exposed, but not the Valibaba Tepe ignimbrite. At other nearby localities, the biotite-free Valibaba Tepe unit rests directly on top of the biotite-rich Kizilkaya ignimbrite, although their times of emplacement were separated by at least $1.5 \mathrm{Ma}$ (Table 1). The absence of biotite is a distinctive feature of the Valibaba Tepe unit and has important implications for mineral chemistry: oxide grains are remarkably richer in $\mathrm{Ti}$ in comparison to oxides in other ignimbrites (Temel et al., 1998), thus providing a good tool for chemically fingerprinting this widespread welded unit (Table 2). 


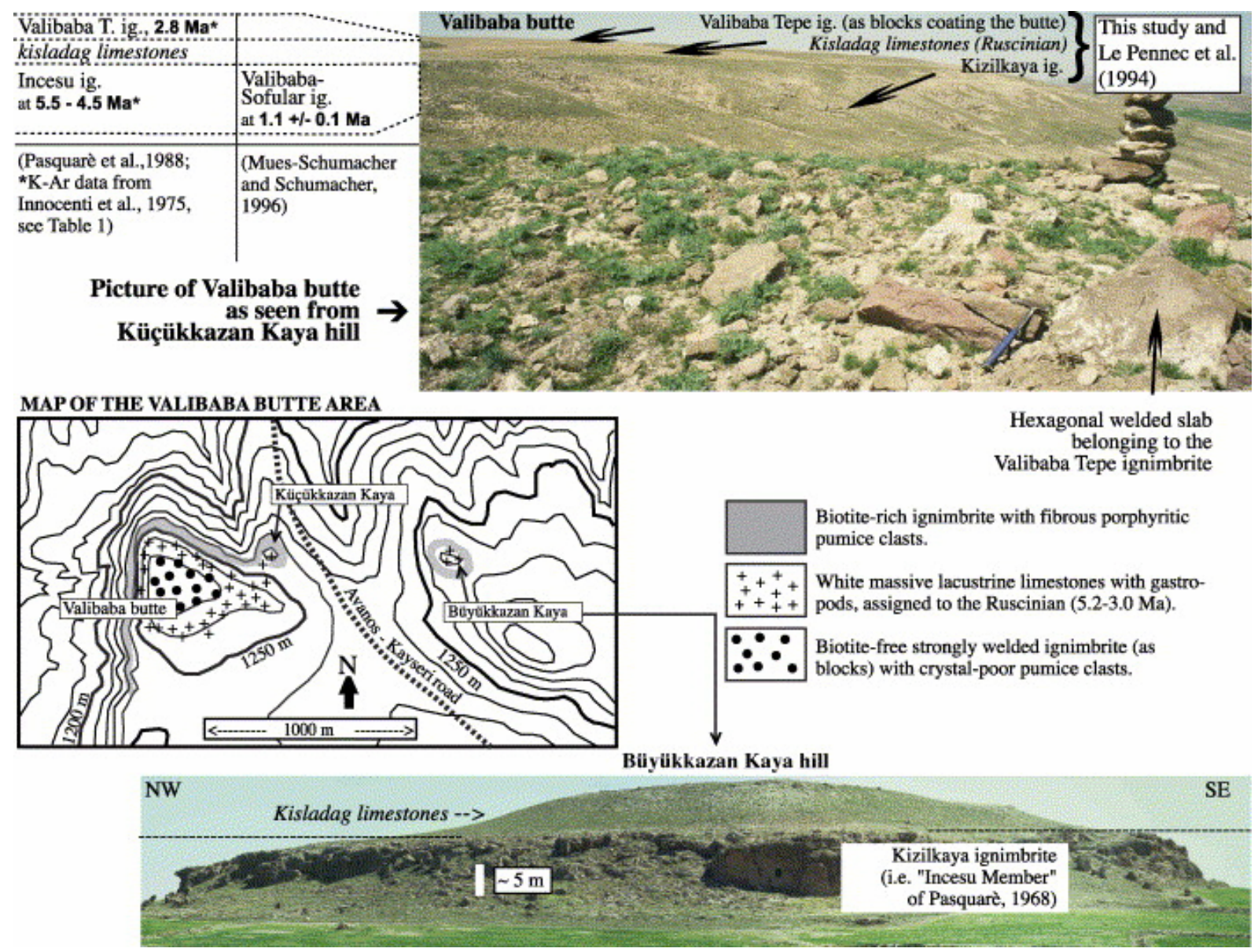

Fig. 5. Sketch map of the Valibaba butte area with illustrations of the stratigraphic schemes and K-Ar ages found in the literature and proposed in this paper. The Valibaba butte is covered with numerous blocks belonging to the 2.8-Ma-old welded and biotite-free Valibaba Tepe ignimbrite. These blocks rest upon limestones of the "Kýpladað Member" (Pasquarè, 1968). We correlate the limestones to the Ruscinian Stage (5.2-3.0 Ma) and they are also shown in Fig. 4 and Fig. 6. Remnants of the Valibaba Tepe ignimbrite are not found on top of the Büyükkazan Kaya hill, above the "Kışladağ Member" limestones. On both hills the limestones overly a biotiterich non-welded ignimbrite that we correlate to the mu5-Ma-old Kizilkaya unit.

Mues-Schumacher and Schumacher (1996) correlated their Valibaba-Sofular unit (i.e., the lower biotite-rich unit of the Valibaba butte) with layer B of Fig. 4 near Sofular village (situated $8-10 \mathrm{~km}$ to the west of Valibaba butte), but did not present any supporting argument that would justify this correlation. In our interpretation, the volcanic layers exposed at the Valibaba butte are much younger (i.e., $<6 \mathrm{Ma}$ ) than those in the Sofular area (i.e., $>6 \mathrm{Ma}$ ). The Valibaba Tepe unit described by Pasquarè (1968), Pasquarè et al. (1988), Le Pennec et al. (1994), Şen et al. (2003) has been dated by Innocenti et al. (1975) on glass fractions from three locations at $2.7 \pm 0.1 \mathrm{Ma}, 2.8 \pm 0.1 \mathrm{Ma}$ and $3.0 \pm 0.1 \mathrm{Ma}$, and by Mues-Schumacher and Schumacher (1996) on a whole-rock sample from Incesu village at $2.8 \pm 0.1 \mathrm{Ma}$ (Table 1). Consequently, the $1.1 \pm 0.1 \mathrm{Ma}$ age obtained by Mues-Schumacher and Schumacher (1996) at Valibaba butte on a biotite fraction from the lower unit is at odds with the $2.8 \pm 0.1 \mathrm{Ma}$ age of the biotite-free Valibaba Tepe ignimbrite located above, on the same butte. The abnormally young $1.1 \pm 0.1 \mathrm{Ma}$ age may reflect some alteration of the parent sample. Our recent analyses of pumice clasts in the same unit yielded LOI values between 3\% and $6 \%$. We therefore think that the lower unit of the Valibaba butte is the $\sim 4.5-5.5 \mathrm{Ma}$ Kizılkaya ignimbrite, as proposed by Le Pennec et al. (1994). This interpretation would be in agreement with the 
reverse magnetic polarity obtained by Piper et al. (2002) and with the 2.8-Ma age of the overlying Valibaba Tepe unit. Furthermore, this would also be compatible with ages obtained by Notsu et al. (1995) on early lavas $(2.5 \pm 0.3 \mathrm{Ma} ; 2.6 \pm 0.1 \mathrm{Ma}$, Table 1 and Fig. 2) of the Quaternary Erciyes volcano which grew at the inferred source of the Valibaba Tepe ignimbrite (Pasquarè, 1968, Pasquarè et al., 1988, Le Pennec et al., 1994 and Şen et al., 2003).

As discussed above, the Incesu unit of Mues-Schumacher and Schumacher (1996) corresponds in age and characteristics to the Valibaba Tepe unit of Pasquarè (1968) and Innocenti et al. (1975). As pointed out earlier, confusion might arise by using the locality name Incesu. We retain the term Valibaba Tepe unit (Pasquarè, 1968, Innocenti et al., 1975 and Pasquarè et al., 1988) because it refers to a correct and accurate definition of the ignimbrite's characteristics, distribution and source vent (i.e., welded biotite-free ignimbrite erupted from a vent below the Erciyes volcano ca. 2.8 Ma ago).

\section{Correlation of the Gördeles and Sofular deposits}

The Gördeles ignimbrite was identified by Pasquarè (1968) above the Cemilköy and Tahar units and below the now-called Kizılkaya unit (Incesu according to Pasquarè's terminology). The age of the Cemilköy unit has been constrained between 8.4 and 7.6 Ma (see above). Unfortunately, the Tahar unit has not yet been K-Ar dated, but Pasquarè (1968) reported vertebrate fossils from the western side of the Damsa valley above the Tahar deposits (which occur at this locality in the form of laharic material derived from the ignimbrite) and below the Gördeles unit: Hipparion matthewi (Abel) and Hipparion cf. mediterraneum (Hansel) are known to occur in the eastern Mediterranean region from Middle to Upper Turolian times, i.e., between 7.6 and 5.2 Ma. Therefore, the Tahar ignimbrite should not be younger than 5.2 $\mathrm{Ma}$, and the Gördeles ignimbrite should not be older than 7.6 Ma. This is compatible with the $\mathrm{K}-\mathrm{Ar}$ age of $7.8 \pm 1.6 \mathrm{Ma}$ reported by Innocenti et al. (1975) for the Gördeles unit. On the other hand, Mues-Schumacher and Schumacher (1996) obtained two similar ages with a weighted average of $4.4 \pm 0.4 \mathrm{Ma}$ for the Gördeles unit (Table 1). This age is almost identical to the weighted average age of $4.3 \pm 0.4 \mathrm{Ma}$ obtained by them for the younger Kizilkaya ignimbrite. Mues-Schumacher and Schumacher (1996) resolve this extreme age proximity by explaining that both eruptions occurred within a very short time interval, and that the accuracy of conventional $\mathrm{K}$-Ar dating of young tephra is not good enough for high frequency eruptive successions. However, field evidence suggests that the amount of time which elapsed between the emplacement of the Gördeles and Kizllkaya ignimbrites might be longer than implied by the K-Ar dates of Mues-Schumacher and Schumacher (1996). At some localities, the Kızılkaya unit rests directly on top of the Gördeles unit, but sections reported in Pasquarè (1968), Temel (1992) and Le Pennec et al. (1994) show that 30 to $50 \mathrm{~m}$ of sediments (compacted clays, marls, limestones and fine-grained clastic deposits) are locally interbedded between the two ignimbrites. Sedimentary successions of similar thickness and lithology between older units were deposited during time periods of at least 0.5-1 Ma (Fig. 2). Below, we argue that the time interval separating the emplacement of the Gördeles and Kizilkaya units is in excess of 1.3 Ma.

Mues-Schumacher and Schumacher (1996) stated that some of their ages might be too young due to argon loss in their pumice samples. This might also be the case for their age obtained on the Gördeles unit because it is in conflict with $\mathrm{K}$-Ar ages obtained on stratigraphically higher ignimbrites and lavas, as evidenced in Fig. 3 and Table 1. Another possibility is that Mues-Schumacher and Schumacher (1996) obtained an extreme age proximity for the two units because they sampled and dated the Kızılkaya unit instead of the Gördeles ignimbrite. 
This seems to be supported by the paleomagnetic results of Piper et al. (2002), as discussed below. In fact, the age of the Kizılkaya unit is not well known. Innocenti et al. (1975) obtained $\mathrm{K}-\mathrm{Ar}$ ages of $5.4 \pm 1.1$ and $4.4 \pm 0.1 \mathrm{Ma}$, while Besang et al. (1977) reported ages of $5.5 \pm 0.2$ and $4.9 \pm 0.2 \mathrm{Ma}$. Innocenti et al. (1975) also reported $\mathrm{K}-\mathrm{Ar}$ ages of $5.1 \pm 0.1$ and $5.0 \pm 0.3 \mathrm{Ma}$ for lavas which, under examination of the geological map by Pasquarè (1968), seem situated above the Kizllkaya ignimbrite sheet. Thus, the Kizılkaya ignimbrite was most probably emplaced between 4.5 and 5.5 Ma (Table 1, Fig. 2).

In this context, the stratigraphic relationship between the Gördeles and the Sofular deposits needs to be clarified. Pasquarè (1968) observed in the eastern part of the Nevşehir Plateau that the Gördeles ignimbrite is below the "Incesu" unit (Kizılkaya in recent literature). He identified the local Sofular unit above his "Incesu" unit. However, as discussed before, it is our opinion that in the area around the Sofular village, Pasquarè (1968) confused the "Incesu" unit (now Kizilkaya) with the much older Tahar unit (layer C in Fig. 4). The same applies to the stratigraphic scheme of Mues-Schumacher and Schumacher (1996). Assuming that layer $\mathrm{C}$ in Fig. 4 correlates with the Tahar unit (Le Pennec et al., 1994), then the Gördeles and Sofular deposits would occur at the same stratigraphic level, i.e., above the Cemilköy and Tahar ignimbrites and below the Kizılkaya sheet ("Incesu" of Pasquarè, 1968). In most previous studies, the stratigraphic relationship between the Sofular and Gördeles units was inferred from the K-Ar datings of Innocenti et al. (1975): the Sofular deposit dated at $6.8 \pm 1.4$ Ma was stratigraphically placed above the Gördeles ignimbrite dated at $7.8 \pm 1.6 \mathrm{Ma}$, although the analytical uncertainties overlap between 6.2 and 8.2 Ma. Le Pennec et al. (1994) did not observe any field relationship between the two deposits, and followed this relative stratigraphy on the basis of the above $\mathrm{K}-\mathrm{Ar}$ ages. They maintained the separation between the Sofular and Gördeles deposits because a notable fall layer is observable below the Sofular unit but not below the Gördeles unit, and because some geochemical differences exist between the two deposits (Table 2 and Temel et al., 1998). However, several lines of evidence suggest that the Sofular unit is part of the Gördeles ignimbrite, an interpretation that is favored here.

(1) The southernmost known exposures of the Sofular deposits are situated only $\sim 9 \mathrm{~km}$ from the northernmost Gördeles ignimbrite outcrops. A NW-SE-oriented valley separates their exposures and hampers correlation of the deposits (Fig. 6). Stratigraphic sections reported by Pasquarè (1968), Temel (1992), and Le Pennec et al. (1994) indicate that the Gördeles and Sofular units are placed at similar levels above the Tahar ignimbrite: the Gördeles unit typically sits $15-23 \mathrm{~m}$ above the Tahar unit southeast of Ürgüp, and the Sofular deposit is seen 8-22 $\mathrm{m}$ above the Tahar unit on the western side of Topuzdağ. The Sofular deposit bears strong similarities (depositional structures, pumice vesiculation textures, mineralogical assemblages, etc.) with the northernmost exposures of the Gördeles ignimbrite. According to the estimates of Le Pennec et al. (1994), the Gördeles unit covers an area of $\sim 3600 \mathrm{~km}^{2}$ which corresponds to a bulk volume of $\sim 110 \mathrm{~km}^{3}$, while the Sofular deposit is distributed over $100 \mathrm{~km}^{2}$, with a bulk volume of about $1 \mathrm{~km}^{3}$. We now suggest that this latter small volume is only a distal part of the voluminous Gördeles unit. 


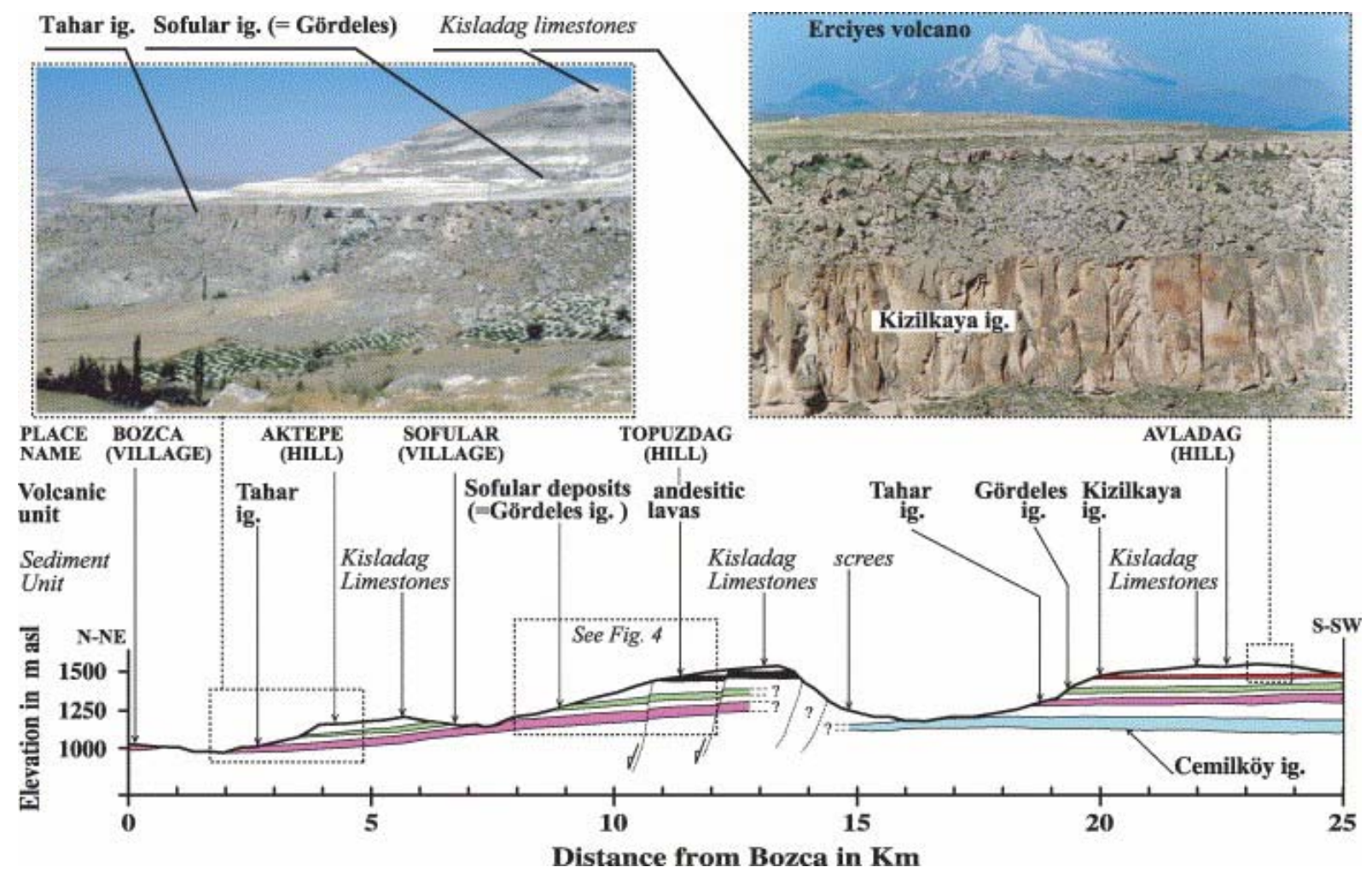

Fig. 6. Schematic cross-section from Bozca village to Avladad hill showing the stratigraphic relationships between major ignimbrite units, as proposed in this study. The trace of the section is shown in the northeastern area of the Nevşehir Plateau in Fig. 1. Vertical scale of the ignimbrites is exaggerated for legibility. Note thinning of ignimbrites toward the North and compare with $\mathrm{K}-\mathrm{Ar}$ ages given in Table 1 and Fig. 2.

(2) A plinian fallout deposit underlies the Sofular unit but not the Gördeles ignimbrite, in which a xenolith-enriched horizon is commonly seen at the base. However, we cannot rule out that the fallout deposit was removed locally during emplacement of the overlying ignimbrite, as is the case of the Kizılkaya ignimbrite.

(3) The source of the Sofular deposit has not been well constrained (Fig. 7). Le Pennec et al. (1994) reported thickness and clast-size variations of the fallout layer that indicate northeastward dispersal of the plinian plume. These observations agree with thickness and clast-size variations of the overlying ignimbrite. The above constraints and the limited extension of the Sofular deposit to the north and west of Topuzdağ led these authors to locate the source below the extensive Topuzdağ andesite lavas. However, we failed to observe more proximal facies outcrops, although the supposedly most proximal exposures occur less than 5 $\mathrm{km}$ from the presumed vent area at Topuzdağ. The Sofular plinian fall layer is well stratified and displays features typical of a distal deposit: the average maximum size of five pumice fragments (MP5) does not exceed $2 \mathrm{~cm}$ in the area north of Topuzdağ. Isopleth maps of the Zelve, Sarýmanden Tepe, and Kizilkaya plinian fallout deposits are reported by Le Pennec et al. (1994). Additional maps were presented by Schumacher and Mues-Schumacher (1997) for their Akdağ-Zelve (our Zelve) unit. These plinian fallout tephra layers allow us to assess the relationships between distance and maximum clast size in the Cappadocia area (Fig. 7). Hence, in analogy to the above-mentioned deposits, the MP5 values found in the Sofular plinian fall layer would be consistent with a source located $30-40 \mathrm{~km}$ of Topuzdağ. Integrating the southwest-to-northeast dispersal pattern of the plinian plume, the source of the 
Sofular deposit might well coincide with that of the Gördeles ignimbrite (Fig. 7), as identified by Le Pennec et al. (1994).

(4) The above assumptions would also be consistent with the flow patterns displayed by both Sofular and Gördeles deposits in the NE sector of the Nevşehir Plateau. Reliable lineation and imbrication directions measured at the base of both deposits (Fig. 7) indicate a northeastward flow, extending sub-radially away from the Gördeles source. In the same area of the Nevşehir Plateau, this flow pattern correlates with a reduction of the deposits' thickness (from about 20-30 near Ayvalý to 9-16 $\mathrm{m}$ in the Avladağ area, and less than $15 \mathrm{~m}$, or more commonly less than $10 \mathrm{~m}$, north of Topuzdağ).

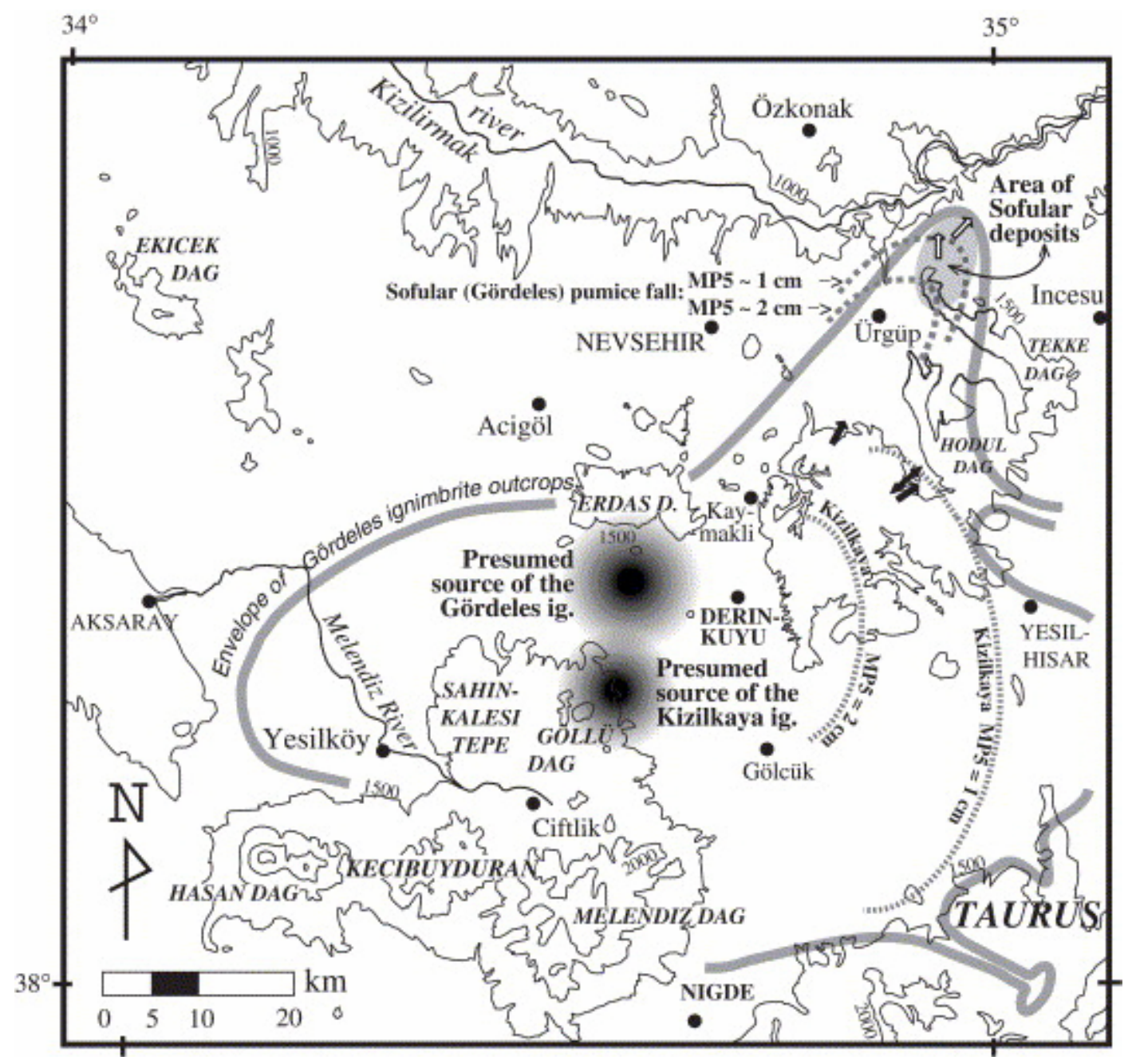

Fig. 7. Map showing the distribution of the Gördeles and Sofular deposits. The thick gray line represents the envelope of the Gördeles ignimbrite outcrops. According to our interpretation, the Sofular unit described by Pasquarè (1968), is also included within the envelope and is indicated as a light gray area. The isopleths for the plinian fallout below the Sofular deposits are shown for MP5=1 and $2 \mathrm{~cm}$ as two gray dashed lines, Northeast of Ürgüp. Flow directions deduced from clast imbrication are represented as open arrows at the base of the Sofular deposits, and by solid arrows at the base of the Gördeles ignimbrite. The solid double arrow south of Ürgüp is a flow lineation measured from scouring structures at the base of the Gördeles ignimbrite. The isopleths MP5=1 and $2 \mathrm{~cm}$ for the Kizılkaya plinian fallout layer are also shown and discussed in the text. 
The above evidence supports a correlation of the Sofular deposit with the Gördeles ignimbrite. Considering the geochronological uncertainties, it is noteworthy that the $\mathrm{K}-\mathrm{Ar}$ ages obtained by Innocenti et al. (1975) for the Gördeles and Sofular units do largely overlap between 6.2 and $8.2 \mathrm{Ma}$. This range is compatible with the $7.0 \pm 0.15 \mathrm{Ma}$ age of the Topuzdag lava situated above the Sofular deposit (Fig. 4) as well as with the Middle to Upper Turolian age (7.6-5.2 Ma) of the mammalian remains found below the Gördeles unit. The age of the fossil assemblage found above the Sofular deposit ranges between 11.0 and 5.2 Ma, and more probably between 8.7 and $6.7 \mathrm{Ma}$. These independent age constraints indicate that the most probable absolute age for the Gördeles (including Sofular) unit is to be sought at some time between 7.6 and $6.8 \mathrm{Ma}$. Thus, the Gördeles unit would be at least 1.3 Ma older than the Kizilkaya unit. As a result, the $4.4 \pm 0.4 \mathrm{Ma}$ age obtained by Mues-Schumacher and Schumacher (1996) for the Gördeles unit would be too young. The above bio- and radiochronologic considerations allow us to constrain the age limits for the Tahar unit (situated below the Gördeles ignimbrite and above the Cemilköy unit and the Damsa lavas) between 7.2 and $7.8 \mathrm{Ma}$ (Table 1, Fig. 2).

\section{Implication for magnetostratigraphy and magnetic fabric studies}

Magnetic properties of ignimbrite samples are valuable stratigraphic tools, helpful in distinguishing different sheets or in highlighting incorrect correlation of deposits if opposite polarities are evidenced. In favorable cases, the ignimbrites can also be dated if the magnetic polarity sequence is locally well established. However, a number of syn- and-post depositional processes may affect magnetic properties and complicate their interpretation (e.g., Hildreth and Mahood, 1985 and Lipman et al., 1996). Piper et al. (2002) have recently obtained several paleomagnetic data on the Cappadocia ignimbrites which illustrate both the potential and limitations of this technique for the purpose of ignimbrite stratigraphy. These authors claimed that the emplacement of the Cappadocian succession embraced a time interval during which reversals of the geomagnetic field were too frequent to be of value for constraining emplacement ages using the Geomagnetic Polarity Time Scale (GPTS) compiled by Cande and Kent (1995). Subsequently, Piper et al. (2002) stated that the limits on the K-Ar age determinations embrace polarities resolved by paleomagnetic study. However, in the Cappadocia case, the paleomagnetic sampling is not dense enough in the sequence, and constraints on "absolute" age from K-Ar dates of the literature are too poor to establish a convincing correlation with the GPTS, apart from the notable exception of the Valibaba Tepe unit.

For each $\mathrm{K}-\mathrm{Ar}$ date reported in the literature and its respective analytical uncertainty (Table 1), we have calculated the amount of time corresponding to normal and reverse polarity (Table 3) using the GPTS compilation of Cande and Kent (1995). Scores in Table 3 are expressed in percent of the time spent in normal or reverse polarity, within the limits of the error interval. The unique case of an ignimbrite for which a magnetic chron can be unambiguously assigned is the normal-polarity Valibaba Tepe unit (Pasquarè, 1968, Innocenti et al., 1975, Pasquarè et al., 1988, Le Pennec et al., 1994 and Şen et al., 2003) that is almost equivalent to the Incesu unit of Mues-Schumacher and Schumacher (1996) and Piper et al. (2002). Data in Table 3 indicate that the duration of the C2An.1n normal chron is larger than the time embraced by the analytical errors of three $\mathrm{K}-\mathrm{Ar}$ ages obtained for the Valibaba Tepe unit. The fourth age gives a score of $70 \%$ in normal polarity, and the unique contender is also the C2An.1n chron. The 1.1 $\pm 0.1 \mathrm{Ma} \mathrm{K}-\mathrm{Ar}$ age obtained for the Valibaba-Sofular ignimbrite 
by Mues-Schumacher and Schumacher (1996) embraces a time interval between 1.0 and 1.2 Ma which dominantly $(65 \%)$ corresponds to a reverse polarity in the GPTS of Cande and Kent (1995). The unique contender would thus be the subchron between normal events C2n and C1r.1n, in the Matuyama epoch, as inferred by Piper et al. (2002). However, we have shown earlier that this age is in conflict with field studies and other $\mathrm{K}-\mathrm{Ar}$ dates, and with paleontologic age constraints which all indicate that the Sofular deposits (layer B in Fig. 4) are not younger than $6.8 \mathrm{Ma}$. The magnetostratigraphic attribution to the Matuyama epoch is thus invalidated. Several anomalously young $\mathrm{K}-\mathrm{Ar}$ ages by Mues-Schumacher and Schumacher (1996), on which Piper et al. (2002) based their paleomagnetic study, probably explain why the latter authors obtained a rotation rate, for the Central Anatolia region, which accelerated during the latter part of the Quaternary. This elevated rotation rate is ca an order of magnitude higher than rates determined from Global Positioning System measurements (Barka and Reilinger, 1997).

Table 3. : Comparison of magnetic polarity and $\mathrm{K}-\mathrm{Ar}$ ages published in the literature (see Table 1)

\begin{tabular}{|c|c|c|c|c|c|c|c|c|c|c|c|}
\hline $\begin{array}{c}\text { Name in } \\
\text { this study } \\
\text { (see Figure 2) }\end{array}$ & $\begin{array}{l}\text { Name in } \\
\text { original } \\
\text { paper }\end{array}$ & $\begin{array}{c}\text { Nature of } \\
\text { sample } \\
\{1\}\end{array}$ & $\begin{array}{l}\text { Ref. } \\
\{2\}\end{array}$ & $\begin{array}{c}\text { Strati- } \\
\text { graphic } \\
\text { position }\end{array}$ & $\begin{array}{c}\text { K-Ar age } \\
\text { (mid-point) } \\
\text { (Ma) }\end{array}$ & $\begin{array}{l}\text { error } \\
\text { in }+/= \\
(\mathrm{Ma})\end{array}$ & $\begin{array}{l}\text { Youngest } \\
\text { age limit } \\
\text { (Ma) }\end{array}$ & $\begin{array}{l}\text { Oldest } \\
\text { age limit } \\
\text { (Ma) }\end{array}$ & $\begin{array}{l}\text { Score in } \\
\text { normal } \\
\text { polarity }\end{array}$ & $\begin{array}{l}\text { Score in } \\
\text { reverse } \\
\text { polarity }\end{array}$ & $\begin{array}{l}\text { Polarity in } \\
\text { Piper et al., } \\
2002\end{array}$ \\
\hline Kizilkaya & Valibaba-Solular & B. & 4 & 12.5 & 1.1 & 0.1 & 1.0 & 1.2 & $35 \%$ & $65 \%$ & Reverse \\
\hline Valibaba Tepe & Valibaba Tepe & G. & 1 & 12 & 2.7 & 0.1 & 2.6 & 2.8 & $100 \%$ & $0 \%$ & \multirow{4}{*}{ Normal } \\
\hline Valibaba Tepe & Valibaba Tepe & G. & 1 & 12 & 2.8 & 0.1 & 2.7 & 2.9 & $100 \%$ & $0 \%$ & \\
\hline Valibaba Tepe & Incesu & W.R. & 4 & 12 & 2.8 & 0.1 & 2.7 & 2.9 & $100 \%$ & $0 \%$ & \\
\hline Valibaba Tepe & Valibaba Tepe & G. & 1 & 12 & 3.0 & 0.1 & 2.9 & 3.1 & $70 \%$ & $30 \%$ & \\
\hline Kizilkaya & Kizilkaya & B. & 4 & 11 & 4.3 & 0.2 & 4.1 & 4.5 & $33 \%$ & $67 \%$ & \multirow{7}{*}{ Reverse } \\
\hline Kizilkaya & Kizilkaya & W.R. & 4 & 11 & 4.3 & 0.2 & 4.1 & 4.5 & $33 \%$ & $67 \%$ & \\
\hline Kizilkaya & Kizilkaya & $\mathrm{Pl}$. & 4 & 11 & 4.5 & 0.2 & 4.3 & 4.7 & $35 \%$ & $65 \%$ & \\
\hline Kizilkaya & Karahôyük & B. & 1 & 11.5 & 4.4 & 0.1 & 4.3 & 4.5 & $10 \%$ & $90 \%$ & \\
\hline Kizilkaya & Kizillkaya & B. & 2 & 11 & 4.9 & 0.2 & 4.7 & 5.1 & $52 \%$ & $48 \%$ & \\
\hline Kizilkaya & Baskồy & B. & 1 & 9.5 & 5.4 & 1.1 & 4.3 & 6.5 & $43 \%$ & $57 \%$ & \\
\hline Kizilkaya & Kizilikaya & B. & 2 & 11 & 5.5 & 0.2 & 5.3 & 5.7 & $0 \%$ & $100 \%$ & \\
\hline Topuzdag lavas & Topuzdag tavas & W.R. & 3 & 10 & 7.0 & 0.2 & 6.8 & 7.2 & & & \\
\hline Gördeles & Sofular & B. & 1 & 9 & 6.8 & 1.4 & 5.4 & 8.2 & $47 \%$ & $53 \%$ & \multirow{4}{*}{ Reverse } \\
\hline Kizilkaya ?? & Gördeles & W.R. & 4 & 8 & 4.0 & 0.2 & 3.8 & 4.2 & $5 \%$ & $95 \%$ & \\
\hline Kizilkaya ?? & Gördeles & W.R. & 4 & 8 & 4.5 & 0.2 & 4.3 & 4.7 & $35 \%$ & $65 \%$ & \\
\hline Gördeles & Gördeles & B. & 1 & 8 & 7.8 & 1.6 & 6.2 & 9.4 & $47 \%$ & $53 \%$ & \\
\hline Cemilköy & Cemilköy & W.R. & 4 & 6 & 6.5 & 0.2 & 6.3 & 6.7 & $67 \%$ & $33 \%$ & \multirow{2}{*}{ Reverse } \\
\hline Cemilkoy & Cemilkóy & W.R. & 4 & 6 & 6.8 & 0.2 & 6.6 & 7.0 & $39 \%$ & $61 \%$ & \\
\hline Damsa Lava & Damsa Lava & W.R. & 3 & 5 & 8.2 & 0.2 & 8.0 & 8.4 & & & \\
\hline Sarimaden Tepe & Sarimaden Tepe & B. & 1 & 4 & 8.0 & 1.6 & 6.4 & 9.6 & $44 \%$ & $56 \%$ & \multirow{3}{*}{ Reverse } \\
\hline Sarimaden Tepe & Akkōy & B. & 1 & 4 & 8.5 & 0.2 & 8.3 & 8.7 & $0 \%$ & $100 \%$ & \\
\hline Sarimaden Tepe & Sarimaden Tepe & B. & 1 & 4 & 8.6 & 1.7 & 6.9 & 10.3 & $53 \%$ & $47 \%$ & \\
\hline Zelve & Akdag-Zelve & W.R. & 4 & 3 & 7.5 & 0.2 & 7.3 & 7.7 & $53 \%$ & $47 \%$ & \multirow{2}{*}{ Normal } \\
\hline Zelve & Akdag-Zelve & W.R. & 4 & 3 & 7.7 & 0.2 & 7.5 & 7.9 & $78 \%$ & $22 \%$ & \\
\hline Kavak & Kavak & B. & 1 & 2 & 8.6 & 1.7 & 6.9 & 10.3 & $53 \%$ & $47 \%$ & \multirow{6}{*}{ Normal } \\
\hline Kavak & Upper Gōreme & W.R. & 4 & 2 & 6.9 & 0.2 & 6.7 & 7.1 & $39 \%$ & $61 \%$ & \\
\hline Kavak & Upper Göreme & W.R. & 4 & 2 & 7.3 & 0.2 & 7.1 & 7.5 & $34 \%$ & $66 \%$ & \\
\hline Kavak & Upper Gôreme & B. & 4 & 2 & 8.7 & 0.2 & 8.5 & 8.9 & $50 \%$ & $50 \%$ & \\
\hline Kavak & Upper Göreme & B. & 4 & 2 & 9.2 & 0.2 & 9.0 & 9.4 & $26 \%$ & $74 \%$ & \\
\hline Kavak & Kavak & B. & 3 & 1 & 11.2 & 2.5 & 8.7 & 13.7 & $50 \%$ & $50 \%$ & \\
\hline
\end{tabular}

Scores are expressed in $\%$ in the amount of time spent in normal or reverse polarity, within the limits of the error interval. The scores are compared to the magnetic polarity obtained by Piper et al. (2002). 1 Abbreviations on the nature of samples; B.: Biotite; G.: Glass; P1.: plagioclase; W.R.: Whole Rock; 2 references: 1: Innocenti et al. (1975); 2: Besang et al. (1977); 3: Temel (1992); 4: Mues-Schumacher and Schumacher (1996).

Piper et al. (2002) found a reverse polarity for the K1z1lkaya and Gördeles units, but ascribe their site 16 to the Gördeles unit in p. 250 and to the Kizilkaya unit in their Table 1 (p. 240), which suggests a possible correlation confusion. We further note that the thermal demagnetization curves are identical for both their Kızılkaya and Gördeles samples (number 13-7 and 17-3, respectively, in their Fig. 6, p. 247). Furthermore, the ages obtained for these units by Mues-Schumacher and Schumacher (1996), and on which Piper et al. (2002) based their magnetostratigraphy, are analytically indistinguishable (Table 1), although the evidence discussed above strongly suggests that their emplacement was separated by a time interval 
longer than 1.3 Ma. We surmise a possible confusion by these authors between the Gördeles and Kizilkaya ignimbrites, rooted in the strong resemblances displayed by both units at various localities. In the case of the Kizılkaya ignimbrite, our calculations favor a reverse polarity (score of $71 \%$ in Table 2) which is consistent with the paleomagnetic results of Piper et al. (2002). Nevertheless, six distinct subchrons (events between C2An.3n and C3An.2n) are potential correlation candidates, but the available $\mathrm{K}-\mathrm{Ar}$ dates do not allow further resolution. In the case of older units, the accuracy of the $\mathrm{K}-\mathrm{Ar}$ ages is very low and the scores in Table 3 approach equi-probability (i.e., $\approx 50 \%$ of time interval during both normal and reverse polarity). Piper et al. (2002) obtained an "anomalous" magnetization for one of their two Tahar unit-sampling sites. These contradictory results might have derived from wrongly correlating different units.

The anisotropy of magnetic susceptibility (AMS) map of Piper et al. (2002) presents northeastward flow directions for the Kizllkaya ignimbrite at their sites 12 and 15, in agreement with previous shape and AMS fabric measurements from the same area (Le Pennec et al., 1998 and Le Pennec, 2000), but in conflict with the northward flow pattern reported in the same area by Schumacher and Mues-Schumacher (1996). This contradiction stems from the wrong correlation of different units by the latter authors, in the area north of Topuzdag. There, they correlated the Tahar unit (whose flow pattern is to the north) with the Kizilkaya unit. In addition, Piper et al. (2002) determined at their sites 23, 25 and 26, axes of preferred magnetization oriented to the North, or to the North-East (if tilt-corrected) for the Sarımaden Tepe unit. This is in agreement with the N-NE clast fabric orientation pattern obtained by Le Pennec et al. (1994) in the same sector.

\section{Conclusion}

The stratigraphy and age of the Cappadocia ignimbrites, Central Turkey, have been addressed in several previous studies. However, in some cases, correlation errors in the field have resulted in diverging stratigraphic interpretations, and in others, differing $\mathrm{K}-\mathrm{Ar}$ ages have led to propose artificial flow units, although field observations, as well as geochemical and paleomagnetic analyses, suggest that the dated samples belong to a single ignimbrite. Here, we have used the chronostratigraphy of selected mammalian taxa and associations, whose remains have been recovered in the interbedded continental sediments, to constrain the ignimbrite ages. At several localities, the radiometric dates obtained on the ignimbrites are significantly younger than the age limits inferred from the paleontologic age constraints. Argon loss from pumice samples leading to relative radiometric "rejuvenation" may explain these age discrepancies. These findings confirm that $\mathrm{K}-\mathrm{Ar}$ ages should be used with caution when dealing with ignimbrite correlation, as recognized before at other ash-flow provinces (e.g., de Silva, 1989, de Silva and Francis, 1989, Self et al., 1991, Lipman et al., 1996 and Lindsay et al., 2001). Problems especially arise in Cappadocia because the ignimbrite eruption frequency is higher than the resolution of many published $\mathrm{K}-\mathrm{Ar}$ ages. Further errors on ignimbrite ages may be introduced in the weighted average $\mathrm{K}-\mathrm{Ar}$ ages if the calculations incorporate too many "rejuvenated" dates. The Cappadocia succession is the only example known to us in which the chronostratigraphy of selected vertebrate taxa provides in some cases better constraint on the ignimbrite age than inaccurate or anomalously young $\mathrm{K}-\mathrm{Ar}$ dates.

The combined age constraints assessed here, which led to revision of the age ranges for the Cappadocia ignimbrites, are consistent with the stratigraphy and correlation framework of Le Pennec et al. (1994). One important alteration, however, is that we now merge the previous 
small-volume Sofular ignimbrite into the widespread Gördeles ignimbrite. Our stratigraphic scheme and correlations are compatible with all $\mathrm{K}-\mathrm{Ar}$ ages published by Innocenti et al. (1975), Besang et al. (1977), Temel et al. (1998), and with some ages obtained by MuesSchumacher and Schumacher (1996). They are also consistent with all paleontologic constraints compiled by Pasquarè (1968), Sickenberg et al. (1975) and Gaziry (1976), and updated in the present work. Discrepancies with other K-Ar ages, principally those obtained by Mues-Schumacher and Schumacher (1996), are attributed to argon loss in the samples. The magnetostratigraphy and tectonic rotation rates of Central Anatolia proposed by Piper et al. (2002), which are based on the K-Ar ages of Mues-Schumacher and Schumacher (1996), would require revisions (with the exception of the $2.8 \mathrm{Ma}$ Valibaba Tepe unit) to meet with the stratigraphic evidence presented in this study.

\section{Acknowledgements}

Reviews by Drs. J. M. Lindsay, C. Siebe and Prof. L. Wilson were helpful to clarify our objectives and to improve the language. The paleomagnetic and $\mathrm{K}-\mathrm{Ar}$ issues were also revised by Prof. Y. Chen (University of Orléans, France) and Dr. V. Bosse (University of Clermont-Ferrand,

France), respectively.

\section{References}

Barka and Reilinger, 1997 A. Barka and R. Reilinger, Active tectonics of the Eastern Mediterranean region deduced from GPS, neotectonic and seismicity data, Ann. Geofis. 40 (1997), pp. 587-610. Abstract-GEOBASE

Beekman, 1966 P.H. Beekman, The Pliocene and Quaternary volcanism in the Hasan DagMelendiz Dag region, M.T.A. Bull., Ankara 66 (1966) 16 pp..

Besang et al., 1977 C. Besang, F.J. Eckhardt, W. Harre, G. Kreuzer and P. Muller, Radiometrische Alterbestimmungen an neogenenen Eruptivgesteinen der Turkei, Geol. Jhb. 25 (1977), pp. 3-36.

Bigazzi et al., 1993 G. Bigazzi, Z. Yegingil, T. Ercan, M. Oddone and M. Ozdoğan, New data for the chronology of central and northern Anatolia by fission track dating of obsidians, Bull. Volcanol. 55 (1993), pp. 588-595

Buist, 1980 D.S. Buist, Columnar sandstone, Island of Bute, Scotland, Geol. Mag. 117 (1980), pp. 381-384.

Cande and Kent, 1995 S.C. Cande and D.V. Kent, Revised calibration of the geomagnetic polarity time scale for the Late Cretaceous and Cenozoic, J. Geophys. Res. 100 (1995), pp. 6093-6095. 
Chaput, 1936 E. Chaput, Voyages d'études géologiques et géomorphologiques en Turquie, Mém. Inst. Fr. d'Archéologie de Stamboul vol. 2 (1936) 312 pp..

de Silva, 1989 S.L. de Silva, Geochronology and stratigraphy of the ignimbrites from the $21^{\circ} 30^{\prime} \mathrm{S}$ to $23^{\circ} 30^{\prime} \mathrm{S}$ portion of the Central Andes of Northern Chile, J. Volcanol. Geotherm. Res. 37 (1989), pp. 93-131.

de Silva and Francis, 1989 S.L. de Silva and P.W. Francis, Correlation of large ignimbritestwo case studies from the Central Andes of Northern Chile, J. Volcanol. Geotherm. Res. 37 (1989), pp. 133-149.

Dhont et al., 1998 D. Dhont, J. Chorowicz, T. Yürür, J.-L. Froger, O. Köse and N.M. Gündoğdu, Emplacement of volcanic vents and geodynamics of Central Anatolia Turkey. In: A. Gourgaud, Editor, Volcanism in Anatolia, J. Volcanol. Geotherm. Res.vol. 85 (1998), pp. $33-54$.

Froger et al., 1998 J.-L. Froger, J.-F. Lénat, J. Chorowicz, J.-L. Le Pennec, J.-L. Bourdier, O. Köse, O. Zimitoğlu, N.M. Gündoğdu and A. Gourgaud, Hidden calderas evidenced by multisource geophysical data; example of Cappadocian calderas, Central Anatolia. In: A. Gourgaud, Editor, Volcanism in Anatolia, J. Volcanol. Geotherm. Res. vol. 185 (1998), pp. 99-128.

Gaziry, 1976 A.W. Gaziry, Jungtertiäre Mastodonten aus Anatolien (Turkei), Geol. Jahrb., B 22 (1976), pp. 1-143.

Hildreth and Mahood, 1985 E.W. Hildreth and G.A. Mahood, Correlation of ash-flow tuffs, Geol. Soc. Amer. Bull. 96 (1985), pp. 968-974.

Innocenti et al., 1975 F. Innocenti, R. Mazzuoli, G. Pasquarè, F. Radicati di Brozolo and L. Villari, The Neogene calc-alcaline volcanism of Central Anatolia: geochronological data on Kayseri-Nigde area, Geol. Mag. 112 (1975), pp. 349-360.

Innocenti et al., 1982 F. Innocenti, P. Manetti, R. Mazzuoli, G. Pasquarè and L. Villari, Anatolia and north-western Iran. In: R.S. Thorpe, Editor, Andesites, Orogenic Andesites and Related Rocks, The Open University, Department of Earth Sciences, Milton Keynes (1982), pp. 327-349.

Le Pennec, 2000 J.-L. Le Pennec, Identifying ash flow sources with directional data: an application to the Kizilkaya ignimbrite, central Anatolia, J. Geophys. Res. 105 (2000), pp. $28427-28441$.

Le Pennec et al., 1994 J.-L. Le Pennec, J.-L. Bourdier, J.-L. Froger, A. Temel, G. Camus and A. Gourgaud, Neogene ignimbrites of the Nevsehir Plateau (Central Turkey): stratigraphy, distribution and source constraints, J. Volcanol. Geotherm. Res. 63 (1994), pp. 59-87.

Le Pennec et al., 1998 J.-L. Le Pennec, Y. Chen, H. Diot, J.-L. Froger and A. Gourgaud, Interpretation of anisotropy of magnetic susceptibility fabric of ignimbrites in terms of kinematic and sedimentological mechanisms: an Anatolian case-study, Earth Planet. Sci. Lett. 157 (1998), pp. 105-127. 
Lindsay et al., 2001 J.M. Lindsay, S. de Silva, R. Trumbull, R. Emmermann and K. Wemmer, La Pacana caldera, N. Chile: a re-evaluation of the stratigraphy and volcanology of one of the world's largest resurgent calderas, J. Volcanol. Geotherm. Res. 106 (2001), pp. 145-173.

Lipman et al., 1996 P.W. Lipman, M.A. Dungan, L.L. Brown and A. Deino, Recurrent eruption and subsidence at the Platoro caldera complex, southeastern San Juan volcanic field, Colorado: new tales from old tuffs, Geol. Soc. Amer. Bull. 108 (1996), pp. 1039-1055.

Mues-Schumacher and Schumacher, 1996 U. Mues-Schumacher and R. Schumacher, Problems of stratigraphic correlation and new $\mathrm{K}-\mathrm{Ar}$ data for ignimbrites from Cappadocia, Central Turkey, Int. Geol. Rev. 38 (1996), pp. 737-746.

Notsu et al., 1995 K. Notsu, T. Fujitani, T. Ui, J. Matsuda and T. Ercan, Geochemical features of collision-related volcanic rocks in central and eastern Anatolia, Turkey, J. Volcanol. Geotherm. Res. 64 (1995), pp. 171-192.

Ozansoy, 1962 Ozansoy, F., 1962. Unité chronostratigraphique du Néogène Continental de Turquie, en particulier d'Anatolie Centrale et Occidentale. Coll. Ist. CNRS, Paris, 104, 5 pp.

Pasquarè, 1968 G. Pasquarè, Geology of the Cenozoic volcanic area of central Anatolia, Atti Accad. Naz. Lincei 9 (1968), pp. 53-204.

Pasquarè et al., 1988 G. Pasquarè, S. Poli, L. Vezzoli and A. Zanchi, Continental arc volcanism and tectonic setting in Central Anatolia, Turkey, Tectonophysics 146 (1988), pp. 217-230.

Piper et al., 2002 J.D.A. Piper, H. Gürsoy and O. Tatar, Paleomagnetism and magnetic properties of the Cappadocian ignimbrite succession, central Turkey and Neogene tectonics of the Anatolian collage, J. Volcanol. Geotherm. Res. 117 (2002), pp. 237-262.

Rössner and Heissig, 1999 In: G.E. Rössner and K. Heissig, Editors, The Miocene Land Mammals of Europe, Verlag Dr. F. Pfeil, München (1999) 515 pp..

Schischwani, 1974 E. Schischwani, Mineralbestand, chemische und petrographische Zusammensetzung ignimbritischer Gesteine zwischen Aksaray und Kayseri (Zentralanatolien, Türkei), Diss. Universität Freiburg (1974) 115 pp..

Schumacher and Mues-Schumacher, 1996 R. Schumacher and U. Mues-Schumacher, The Kizilkaya ignimbrite - an unusual low-aspect-ratio ignimbrite from Cappadocia, Central Turkey, J. Volcanol. Geotherm. Res. 70 (1996), pp. 107-121.

Schumacher and Mues-Schumacher, 1997 R. Schumacher and U. Mues-Schumacher, The pre-ignimbrite (phreato)plinian and phreatomagmatic phases of the Akdag-Zelve ignimbrite eruption in Central Anatolia, Turkey, J. Volcanol. Geotherm. Res. 78 (1997), pp. 139-153.

Self et al., 1991 S. Self, J.A. Wolff, T.L. Spell, C.E. Skuba and M.M. Morrissey, Revisions to the stratigraphy and Volcanology of the Post-0.5 Ma Units and the Volcanic Section of VC-1 Core Hole, Valles Caldera, New Mexico, J. Geophys. Res. 96 (1991) (B3), pp. 4107-4116. 
Sen, 1994 In: S. Sen, Editor, Les gisements de mammifères du Miocène supérieur de Kemiklitepe, Turquie. 5-Rongeurs, Tubulidentés et Chalicothères, Bull. Muséum Hist. Nat., Paris vol. 161 (1994) sect. C, 240 pp..

Sen et al., 1998 S. Sen, G. Seyitoğlu, L. Karadenizli, N. Kazanc1, B. Varol and H. Araz, Mammalian biochronology of Neogene deposits and its correlation with the lithostratigraphy in the Çankırı-Çorum Basin, central Anatolia, Turkey, Eclogae Geol. Helv., Basel 91 (1998), pp. 307-320.

Şen et al., 2003 E. Şen, B. Kürkçüoğlu, E. Aydar, A. Gourgaud and P.M. Vincent, Volcanological evolution of Mount Erciyes stratovolcano and origin of the Valibaba Tepe ignimbrite (Central Anatolia Turkey), J. Volcanol. Geotherm. Res. 2616 (2003), pp. 1-23.

Şenyürek, 1954 M.S. Şenyürek, A Study of the Remains of Samotherium found at Taskinpaşa vol. 12, Rev. Fac. Lan. Hist. Geogr. Univ. Ankara (1954) 32 pp..

Sickenberg et al., 1975 O. Sickenberg, J.D. Becker-Platen, L. Benda, D. Berg, B. Engesser, W. Gaziry, K. Heissig, K.A. Hünermann, P.Y. Sondaar, N. Schmidt-Kittler, K. Staesche, U. Staesche, P. Steffens and H. Tobien, Die Gliederung des höheren Jungtertiärs und Altquartärs in der Turkei nach Vertebraten und ihre Bedeutung für die internationale NeogenStratigraphie, Geol. Jahrb., B 15 (1975), pp. 1-167.

Temel, 1992 Temel, A., 1992. Kapadokya eksplosif volkanısmasının: petrolojik ve jeokimyasal özellikleri. Doc. Thesis, Hacettepe Univ., Ankara, 209 pp.

Temel et al., 1998 A. Temel, N. Gündoğdu, A. Gourgaud and J.-L. Le Pennec, Ignimbrites of Cappadocia (Central Anatolia, Turkey): petrology and geochemistry. In: A. Gourgaud, Editor, Volcanism in Anatolia, J. Volcanol. Geotherm. Res. vol. 185 (1998), pp. 447-471 